\title{
Oxidative Transformations of Lignans
}

\author{
Patrik A. Runeberg ${ }^{\circledR}$, Yury Brusentsev ${ }^{\circledR}$, Sabine M. K. Rendon ${ }^{\circledR}$ and Patrik C. Eklund * \\ Johan Gadolin Process Chemistry Center, Åbo Akademi University, Piispankatu 8, 20500 Turku, Finland; \\ patrik.runeberg@abo.fi (P.A.R.); ybrusent@abo.fi (Y.B.); srendon@abo.fi (S.M.K.R.) \\ * Correspondence: paeklund@abo.fi; Tel.: +358-2-215-4720
}

Academic Editor: David Barker

Received: 16 November 2018; Accepted: 29 December 2018; Published: 15 January 2019

\begin{abstract}
Numerous oxidative transformations of lignan structures have been reported in the literature. In this paper we present an overview on the current findings in the field. The focus is put on transformations targeting a specific structure, a specific reaction, or an interconversion of the lignan skeleton. Oxidative transformations related to biosynthesis, antioxidant measurements, and total syntheses are mostly excluded. Non-metal mediated as well as metal mediated oxidations are reported, and mechanisms based on hydrogen abstractions, epoxidations, hydroxylations, and radical reactions are discussed for the transformation and interconversion of lignan structures. Enzymatic oxidations, photooxidation, and electrochemical oxidations are also briefly reported.
\end{abstract}

Keywords: lignans; oxidation

\section{Introduction}

Lignans constitute a group of natural phenolics found in plant species. They have been identified in around 70 families in the plant kingdom, for example in trees, grasses, grains, and vegetables. Lignans are found in roots, rhizomes, stems, leaves, seeds, and fruits, from where they are usually isolated through extraction with an appropriate solvent. They have a diverse structure built up from two phenyl propane units with different degrees of oxidation in the propane moiety and different substitution patterns in the aromatic rings. Lignans have been shown to have a wide range of biological activities such as antibacterial and insecticidal effects in plants, and anti-cancerous, antiviral, anti-inflammatory, immunosuppressive, anti-diabetic, and antioxidant properties in mammals [1-6]. In addition, many lignans have been found in different foods and feeds, and have been associated with health benefits, such as antioxidant activity and anticancer properties [7-10]. The structure and occurrence of lignans have previously been extensively reviewed in the literature. In some of these reviews the chemical transformations and oxidative degradations have partially been described, mainly for determination of structures [6,11-16]. More recently, advances in the chemistry of lignans, including transformations and interconversions of different lignans, were reviewed by Ward [17]. Although synthetic modifications and interconversions have been extensively reported for lignans, a specific overview on oxidative transformations has not been published. Oxidative transformations of lignan structures can be found in various fields: in total synthesis, in biosynthesis, in antioxidant studies, in oxidative degradations, and as part of targeted chemical transformations. In this paper, we report an overview on oxidative transformations of lignan structures, where the focus is put on transformations targeting a specific structure, a specific reaction, or an interconversion of the lignan skeleton. Oxidative transformations related to studies of biosynthetic routes, antioxidant activities, and total syntheses for coupling phenylpropane units (creating the lignan skeleton) are mostly excluded. The purpose of this paper is to exemplify the transformations induced by different reagents or oxidation methods (Table 1). The presented text, figures, and schemes should be taken as representative examples rather than a comprehensive review of the literature. However, the most relevant literature in the field is cited. 
Table 1. Various methods for oxidative transformations of lignans.

\begin{tabular}{|c|c|c|c|}
\hline Non-Metal Ox. & Oxidative Transformation & Yields & Ref. \\
\hline DDQ & $\begin{array}{l}\text { Benzylic hydride abstraction and benzylic ring } \\
\text { closures, Ar-Ar-coupling to } \\
\text { dibenzocyclooctadiene, nucleophilic attack, } \\
\text { alcohol oxidation, aromatization }\end{array}$ & $\sim 10-40 \%$ & [18-37] \\
\hline$m \mathrm{CPBA}$ & $\begin{array}{l}\text { Epoxidation, Baeyer-Villiger oxidation, } \\
\text { oxidation of ethoxy-THF-lignans to lactones }\end{array}$ & $\sim 70-90 \%$ & {$[29,38-42]$} \\
\hline peroxyl radical (ROO·) & $\begin{array}{l}\text { Antioxidative radical scavenging to phenoxyl } \\
\text { radicals and further radical couplings }\end{array}$ & No data & [43-46] \\
\hline $\begin{array}{c}\text { Azo compounds } \\
\text { (AAPH, AIBN, ABTS) }\end{array}$ & Same as above & No data & [46-63] \\
\hline $\mathrm{DPPH}$ & $\begin{array}{l}\text { Same as above, radical } 5-5 \text { couplings to dimers } \\
\text { and oxidation of benzylic alcohol to ketone }\end{array}$ & No data & {$[6,51,64-67]$} \\
\hline TEMPO & Oxidation of benzylic alcohol to ketone & $60 \%$ & [68] \\
\hline BAIB and PIFA & $\begin{array}{l}\text { phenolic hydroxyl oxidation to quinone type } \\
\text { structures, Ar-Ar-coupling to } \\
\text { dibenzocyclooctadienes, nucleophilic attack at } \\
\text { ipso- or benzylic position }\end{array}$ & $\sim 10-80 \%$ & [69-74] \\
\hline IBX & $\begin{array}{l}\text { Aromatic demethylation, benzylic alcohol } \\
\text { oxidation to carbonyl }\end{array}$ & $\sim 25-95 \%$ & [75-79] \\
\hline $\begin{array}{l}\text { Dess-Martin Periodinane } \\
\text { (DMP) }\end{array}$ & $\begin{array}{l}\text { Benzylic alcohol oxidation to carbonyl, } \\
9,9^{\prime} \text {-diol oxidation to lactols }\end{array}$ & $>90 \%$ & [80-89] \\
\hline $\mathrm{NaIO}_{4}$ & $\begin{array}{l}\text { Oxidation of guaiacyl or syringyl groups to } \\
\text { demethylated o-quinones, Lemieux-Johnson } \\
\text { oxidation }\end{array}$ & $\sim 50-95 \%$ & {$[90-100]$} \\
\hline N-Bromosuccinimide (NBS) & $\begin{array}{l}\text { Brominations (arylic or benzylic), benzylic } \mathrm{CH}_{2} \\
\text { to ketone, benzylic ring closure and } \\
\text { aromatization }\end{array}$ & $75-90 \%$ & {$[35,101-107]$} \\
\hline Dimethyldioxirane (DMDO) & Oxidative ring opening of furan rings & $\sim 80 \%$ & [108] \\
\hline Nitrobenzene & $\begin{array}{l}\text { Oxidative degradation to vanillin and } \\
\text { vanillic acid }\end{array}$ & $80-100 \%$ & [109-111] \\
\hline Metal-Mediated Ox. & Oxidative Transformation & Yields & Ref. \\
\hline $\begin{array}{c}\mathrm{Cr}-(\mathrm{VI}) \\
\left(\mathrm{CrO}_{3}, \mathrm{PCC}, \mathrm{PDC}\right)\end{array}$ & $\begin{array}{l}\text { Oxidation of benzylic alcohols to ketones, } \\
\text { primary alcohols into lactones and } \\
\text { carboxylic acid }\end{array}$ & $\sim 60-95 \%$ & $\begin{array}{c}87,103,105, \\
112-120]\end{array}$ \\
\hline $\mathrm{Pd}, \mathrm{Au}$ & $\begin{array}{l}\text { Oxidation of benzylic alcohols in presence of } \\
\text { free phenolic into (mainly) ketone }\end{array}$ & No data & [121-126] \\
\hline $\mathrm{MoOPH}$ & $\alpha$-Hydroxylation & $\sim 25-95 \%$ & {$[113,127-131]$} \\
\hline $\mathrm{MoCl}_{5}$ & Ar-Ar-coupling to dibenzocyclooctadienes & $\sim 50-90 \%$ & {$[132,133]$} \\
\hline $\mathrm{VoF}_{3} ; \mathrm{V}_{2} \mathrm{O}_{5} ; \mathrm{Tl}_{2} \mathrm{O}_{3} ; \mathrm{RuO}_{5}$ & $\begin{array}{l}\text { Ar-Ar-coupling to dibenzocyclooctadienes, } \\
\text { benzylic ring closure }\end{array}$ & $\sim 50-100 \%$ & [134-147] \\
\hline MTO (catalyst) & $\begin{array}{l}\text { Aromatic demethylation and quinone } \\
\text { formation and simultaneous benzylic alcohol } \\
\text { oxidation to ketones, benzylic cleavage, } \\
\text { benzylic hydroxylation, oxidation of benzylic } \\
\text { alcohol to ketone }\end{array}$ & $\sim 40-100 \%$ & [148-150] \\
\hline $\mathrm{Pb}(\mathrm{OAc})_{4}$ & Benzylic acetoxylation & $\sim 30-70 \%$ & [151] \\
\hline $\mathrm{CeCl}_{3}$ & $\alpha$-Hydroxylation & $71 \%$ & [152] \\
\hline Other Oxidations & Oxidative Transformation & Yields & Ref. \\
\hline \multirow{7}{*}{ Electrochemical ox. } & Benzylic ring closure & $37-99 \%$ & [153-155] \\
\hline & Radical $4-O-5$ coupling & $3.6 \%$ & [156] \\
\hline & Oxidation of diol to lactone & No data & [157] \\
\hline & Arylic hydroxylation and rearrangement & No data & [158] \\
\hline & Benzylic hydroxylation & $90 \%$ & [159] \\
\hline & $\begin{array}{l}\text { Demethylation, quinone formation, and } \\
\text { benzylic ring closure }\end{array}$ & No data & [160] \\
\hline & Ar-Ar-coupling to dibenzocyclooctadiene & $>80 \%$ & [161] \\
\hline Photooxidation & $\begin{array}{l}\text { Benzylic: cleavage/alcohol oxidation to } \\
\text { ketone/ring closure/nucleophilic attack }\end{array}$ & No data & [162] \\
\hline
\end{tabular}




\section{Non-Metal-Mediated Oxidations}

\subsection{2,3-Dichloro-5,6-dicyano-1,4-benzoquinone (or DDQ)}

2,3-Dichloro-5,6-dicyano-1,4-benzoquinone (DDQ) has been used to promote benzylic functionalization of lignans by abstraction of a hydride from the benzylic position. The benzylic cation can then be a target for either intramolecular ring closure or nucleophilic attack. The nucleophilicity of the solvent can direct the reaction towards either benzylic ring closure to aryltetralins, or to aryl-aryl coupling to cyclooctadienes, or toward nucleophilic attack by the solvent. In the latter case, a nucleophilic solvent such as $\mathrm{AcOH}$ can function as an oxygen donor. As an example, (-)-dehydroxycubebin was oxidized by DDQ in $\mathrm{AcOH}$, and reacted by either benzylic ring closure to an aryltetralin (1), or by O-acetylation through nucleophilic attack at the benzylic position (2) [18] (Scheme 1). When the solvent was changed to the more acidic and less nucleophilic trifluoroacetic acid (TFA), aryl-aryl coupling to a dibenzocyclooctadiene (3) was favored [19-27].
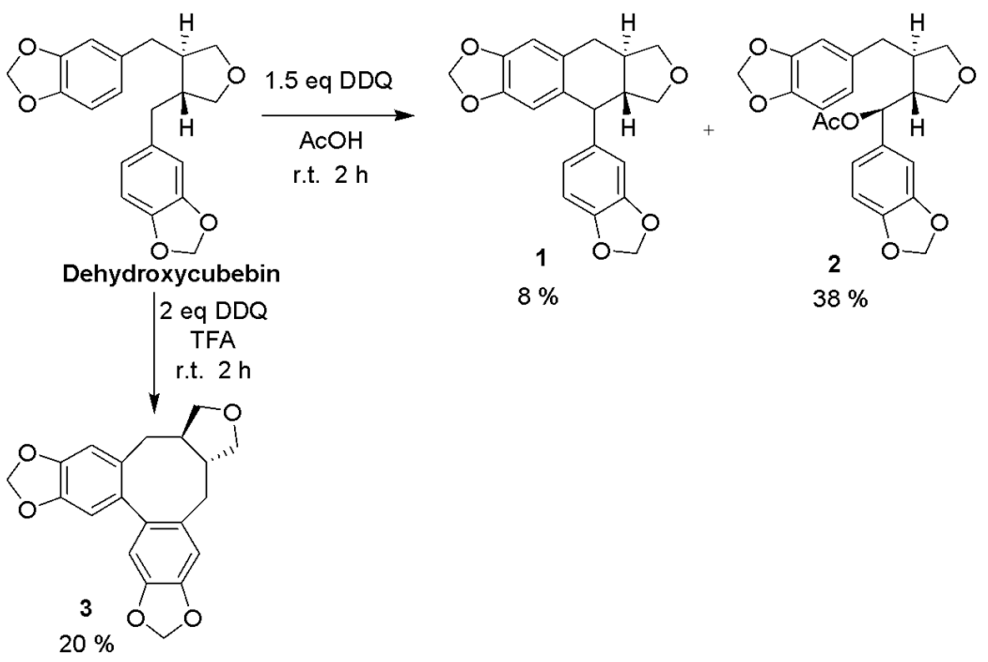

Scheme 1. Oxidation of dehydroxycubebin by DDQ. AcOH promotes benzylic functionalization while TFA promotes aryl-aryl coupling.

Another example of benzylic $\mathrm{O}$-acetylation is shown in Scheme 2. Tomioka et al. reported that the dibenzocyclooctadiene lignan known as (+)-isostegane could be $O$-acetylated at the benzylic position by DDQ in acetic acid, forming (+)-steganacin (Scheme 2) [28].
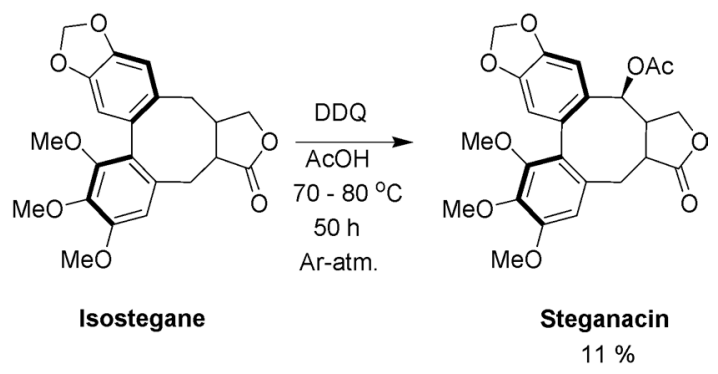

Scheme 2. Benzylic O-acetylation of (+)-isostegane by 2,3-Dichloro-5,6-dicyano-1,4-benzoquinone (DDQ) in $\mathrm{AcOH}$.

A DDQ/TFA-mediated reaction of an epoxy-lignan (5), formed through mCPBA epoxidation of an olefinic lignan (4), did not form the cyclooctadiene as expected. Instead, TFA-induced epoxide opening and methyl or benzyl group rearrangement to two intermediates preceded DDQ mediated ring closure to 6 and 7 (Scheme 3) [29]. One intermediate underwent the previously described ring 
closure to a cyclooctadiene, while the other went through benzylic ring closure to a cyclohexanone, with subsequent ring closure to a benzofuran.
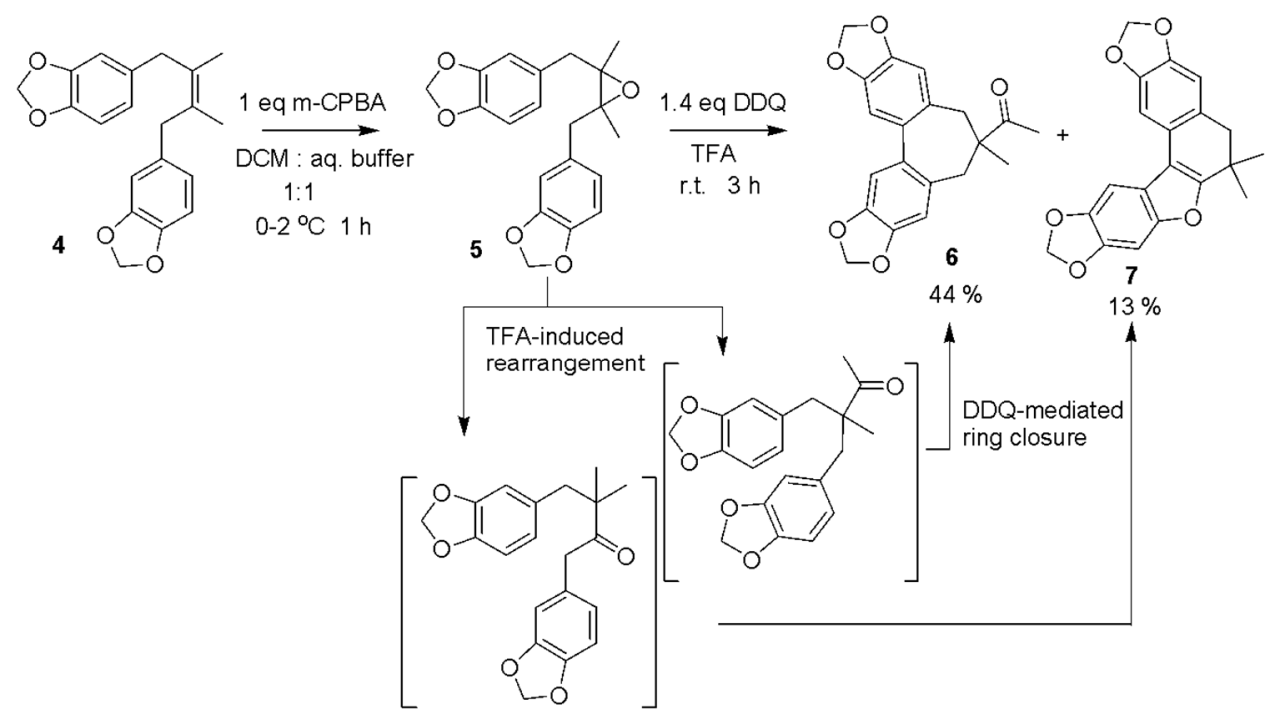

Scheme 3. TFA- and DDQ-mediated rearrangement and oxidative ring closure of an epoxide lignan.

DDQ has also been used for benzylic dehydrogenation of lignan structures to olefins, and in some cases further aromatization to naphthalene type lignans [23,30-32]. One example of benzylic olefin formation is visualized in Scheme 4 by the DDQ oxidation of the natural lignan hydroxymatairesinol (HMR) [33,34]. Due to different stereoelectronic properties at the benzylic alcohol for the hydroxymatairesinol epimers, the oxidation reaction resulted in different major products, of which oxomatairesinol had the highest yield. A range of minor products, which are not shown here, were also formed in the reactions.

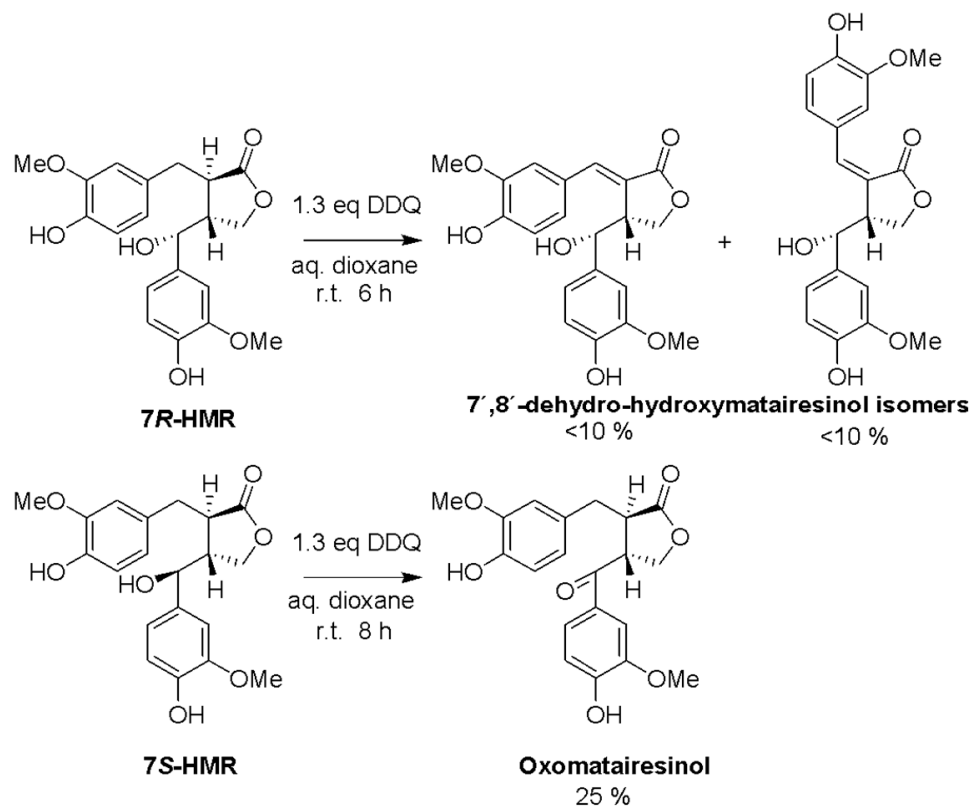

Scheme 4. Oxidation of hydroxymatairesinol (HMR) by DDQ is dependent on the stereochemistry of the benzylic alcohol position. The major products are shown here. A range of minor products were also formed in the reactions.

An example of DDQ-mediated aromatization of lignans is shown in Scheme 5, for the aromatization of isodeoxypodophyllotoxin [35]. 


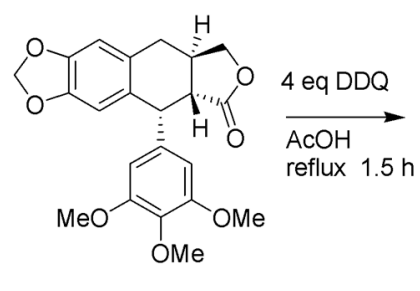

Isodeoxypodophyllotoxin<smiles>COc1cc(-c2c3c(cc4cc5c(cc24)OCO5)COC3=O)cc(OC)c1OC</smiles>

Dehydroanhydropicropodophyllin $43 \%$

Scheme 5. DDQ-mediated aromatization of isodeoxypodophyllotoxin.

When gmelinol reacted with three equivalents of DDQ it underwent benzylic hydride abstraction and C-C-bond rearrangement, followed by an oxidative ring opening of an ether bridge to form an aldehyde, and finally, another benzylic hydride abstraction and formation of olefin (8) [36]. The reaction is visualized in Scheme 6.

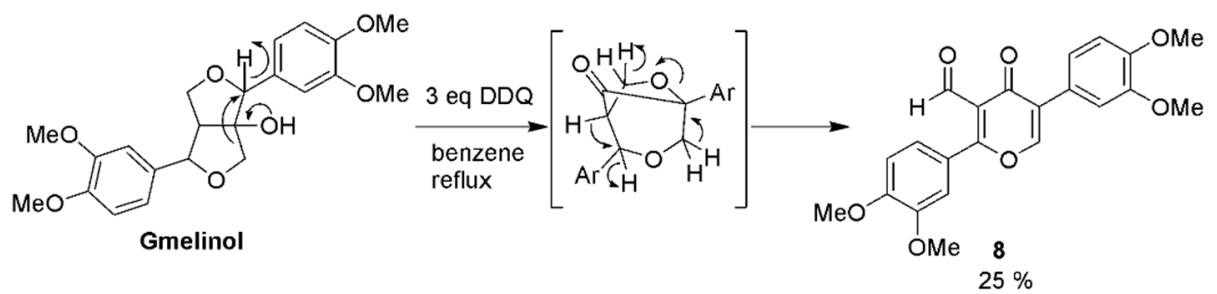

Scheme 6. Oxidation of gmelinol with three equivalents DDQ.

DDQ-mediated epimerization followed by nucleophilic ring closure at the benzylic position is visualized in Scheme 7 on a lignan (9) synthesized from gmelinol [37]. The epimerization step may go through benzylic hydride abstraction, leading to adjacent $\mathrm{C}-\mathrm{C}$ bond cleavage and regeneration. One epimer (10) is favored as it can undergo nucleophilic attack at the positively charged benzylic position, forming product 11.

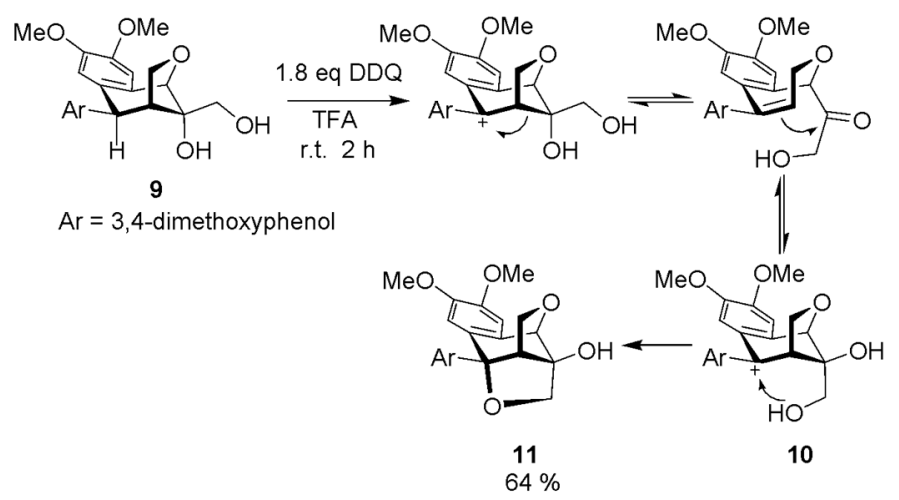

Scheme 7. DDQ-mediated epimerization and nucleophilic ring closure.

\subsection{Meta-Chloroperoxybenzoic Acid ( $m C P B A$ )}

Epoxidation of olefinic lignans with $\mathrm{mCPBA}$ has been reported, as previously shown in Scheme 3 [29,38].

The Bayer-Villiger oxidation of ketones with mCPBA has also been reported for lignans. The 3,7-dioxobicyclo[3,3,0]octane lignan 12 gave the corresponding dilactone product 13 (Scheme 8) [39,40]. In the total synthesis of taiwanin E, the last two steps consist of Baeyer-Villiger of an aldehyde (14) to the corresponding formate (15), followed by hydrolysis by $\mathrm{MeOH}$ and $\mathrm{K}_{2} \mathrm{CO}_{3}$ to the alcohol (Scheme 9) [41] . 


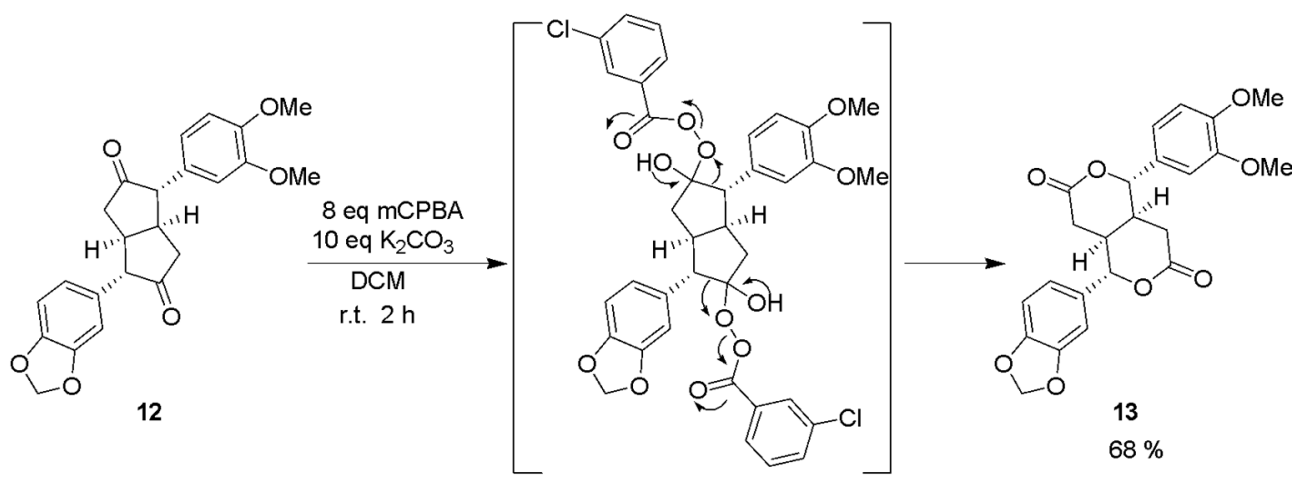

Scheme 8. Baeyer-Villiger oxidation of a diketone to a dilactone.<smiles>[Y4]=C1COc2cc(-c3c4c(c(C=O)c5cc6c(cc35)OCO6)COC4=O)ccc2O1</smiles>

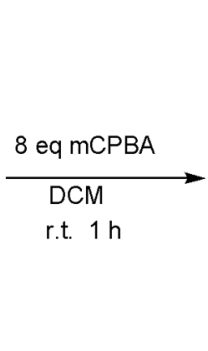<smiles>[13CH3]COc1c2c(c(-c3ccc4c(c3)OCO4)c3c1C(=O)OC3)OCO2</smiles>

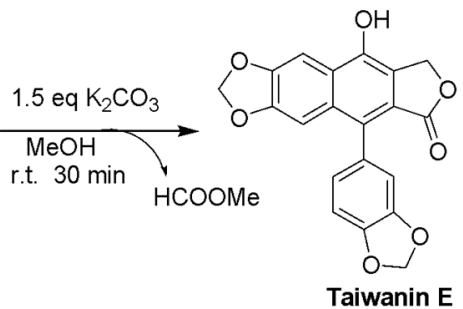

$88 \%$ (2 steps)

Scheme 9. Baeyer-Villiger oxidation of an aldehyde to the corresponding formate, which was further hydrolyzed to the alcohol (taiwanin E).

In addition, mCPBA and Lewis acid mediated oxidation of an ethoxy-THF-lignan (16) to a lactone (17) has been reported (Scheme 10) [42].

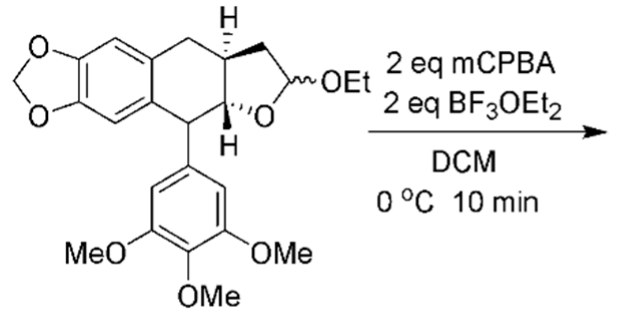

16<smiles>COc1cc(C2c3cc4c(cc3C[C@H]3CC(=O)O[C@H]23)OCO4)cc(OC)c1OC</smiles>

17

Scheme 10. Lewis acid and mCPBA mediated oxidation of an ethoxytetrahydrofuran to the corresponding lactone.

\subsection{Oxidations by Peroxyl Radical}

Radical scavenging of peroxyl radicals has been utilized for measuring antioxidant activity for natural phenolics, including flavonoids [43,44] and lignans [45,46]. The antioxidant activity of lignans is caused by their efficiency to scavenge radicals through hydrogen abstraction, forming phenoxyl radicals. However, in the process, the lignan structure is oxidized and undergoes various transformations. The highly antioxidant active lignan known as secoisolariciresinol was oxidized by two ethyl linoleate peroxide radicals induced by azobisisobutyronitrile (AIBN) to a quinone-like intermediate (18), which formed the lignan lariciresinol through trans-selective ring closure. As a side reaction, a peroxyl radical also undertook radical coupling at the ipso-position of the phenoxyl radical intermediate to 19 (Scheme 11) [45,46]. 


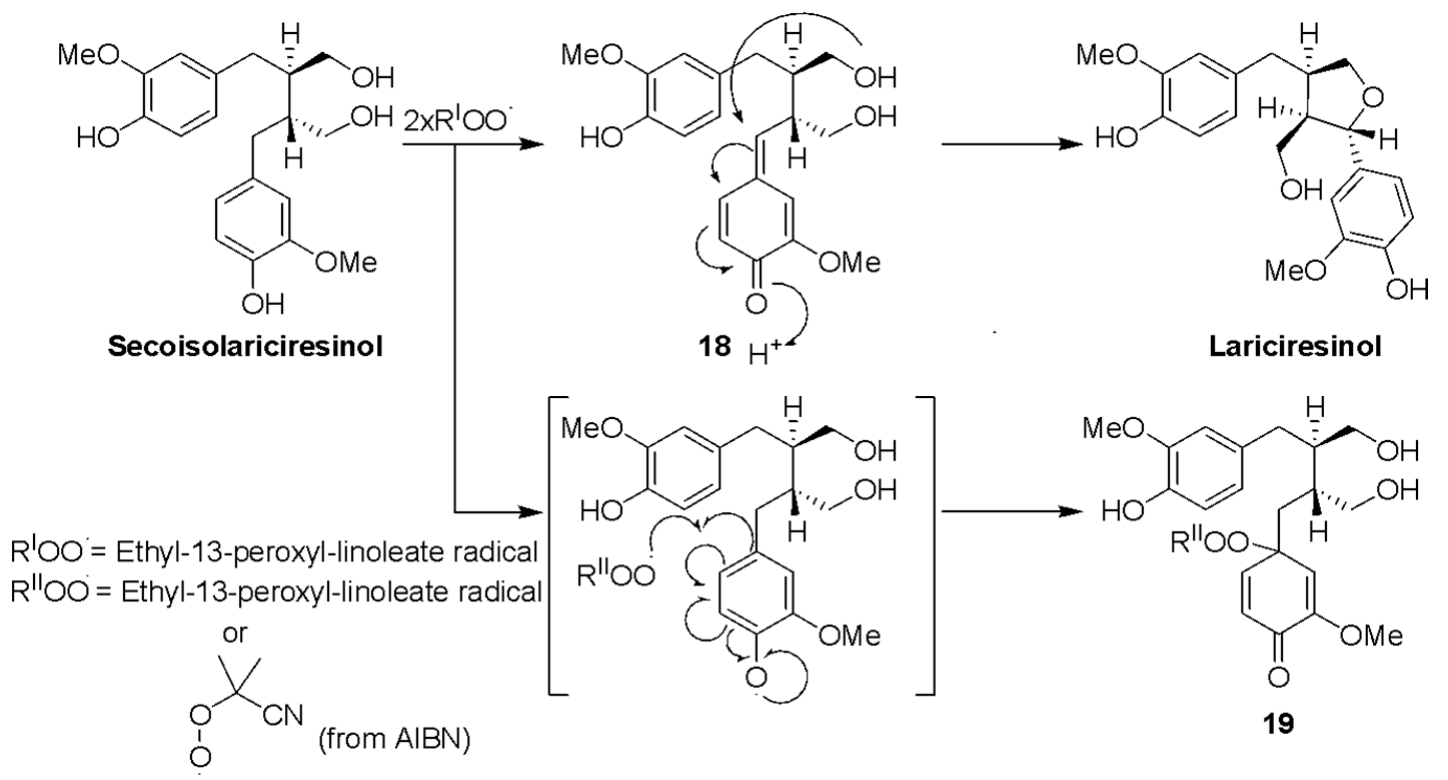

Scheme 11. Peroxyl radical mediated oxidation of the lignan secoisolariciresinol.

\subsection{Azo Compounds (AAPH, AIBN and ABTS)}

2,2'-Azobis(2-amidinopropan) dihydrochloride (AAPH or ABAP), azobisisobutyronitrile (AIBN), and 2,2'-azino-bis(3-ethylbenzothiazoline-6-sulfonic acid) (ABTS) are radical initiators often used in studies of oxidative stability of drugs and proteins, and of antioxidative activity in, among others, food supplements and natural products [47-49]. These azo compounds undergo thermal degradation under release of $\mathrm{N}_{2}$, and formation of two amidino propane (from AAPH) or isobutyronitrile (from AIBN) radicals. These radicals can be transformed into other reactive radical species depending on the reaction environment, for example by oxygen addition into peroxyl radicals [50].

Studies on antioxidant activity on a range of lignans have been done using AAPH, but only in some cases the major oxidation products have been characterized [51-56]. Upon radical scavenging, the lignans form phenoxyl radicals with their radical delocalized over the phenolic ring, followed by radical coupling at either the ipso- or meta-position, or through the para phenoxyl radical. Alternatively, a second radical reaction yields a quinone methide intermediate that reacts further through an ionic mechanism, as shown in Scheme 11 for 18. As an example, secoisolariciresinol primarily reacted through an aryl-aryl coupling, the so called 5-5 coupling, to dimer 20, and through phenoxyl or meta-coupling with an amidino propane radical from AAPH to 21 and 22 respectively [57]. Further hydrolysis of the meta-coupled amidino propane unit formed a furanone product (23). Lariciresinol was also formed through a similar mechanism as described above (in Scheme 11) for peroxyl radicals. Uniquely for secoisolariciresinol, an alternative radical scavenging path is possible. In this path, an intermediate with alkoxyl radicals on one or both aliphatic hydroxyls, reacts through radical coupling with another hydroxyl radical, forming dimer 24, or with water, forming hydroperoxides (25) (Scheme 12).

As described in the previous chapter, AIBN has been used as a radical initiator for peroxyl radicals in antioxidant studies on lignans [46]. As shown in Scheme 11, a possible antioxidant product is formed through ipso-coupling of the lignan with an AIBN derived peroxide. AIBN has also been used in total synthesis of a range of lignans, in aryl halide and $\mathrm{Ru}_{3} \mathrm{SnH} / \mathrm{AIBN}$ initiated radical aryl-aryl couplings [58], and in $\left(\mathrm{Me}_{3} \mathrm{Si}\right)_{3} \mathrm{SiH} / \mathrm{AIBN}$ promoted radical conversion of a thionocarbonate to a lignan lactone [59]. The radical initiator ABTS has also been used for antioxidant studies on lignans [60-63], in the so called trolox equivalent antioxidant capacity (TEAC) assays [163]. However, no systematic study on the formed oxidation products by AIBN or ABTS has been done, excluding the product 19. 


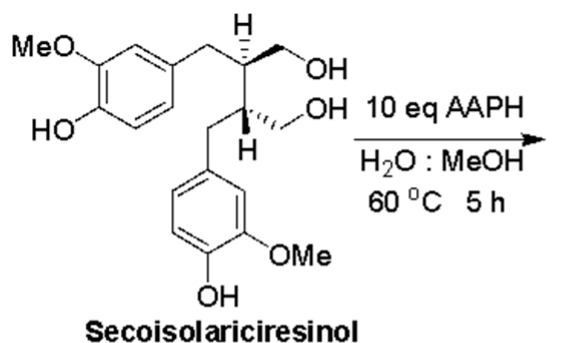<smiles>COc1cc(C[C@@H](CO)[C@H](CO)Cc2ccc(OC)c(OC)c2)ccc1O</smiles>

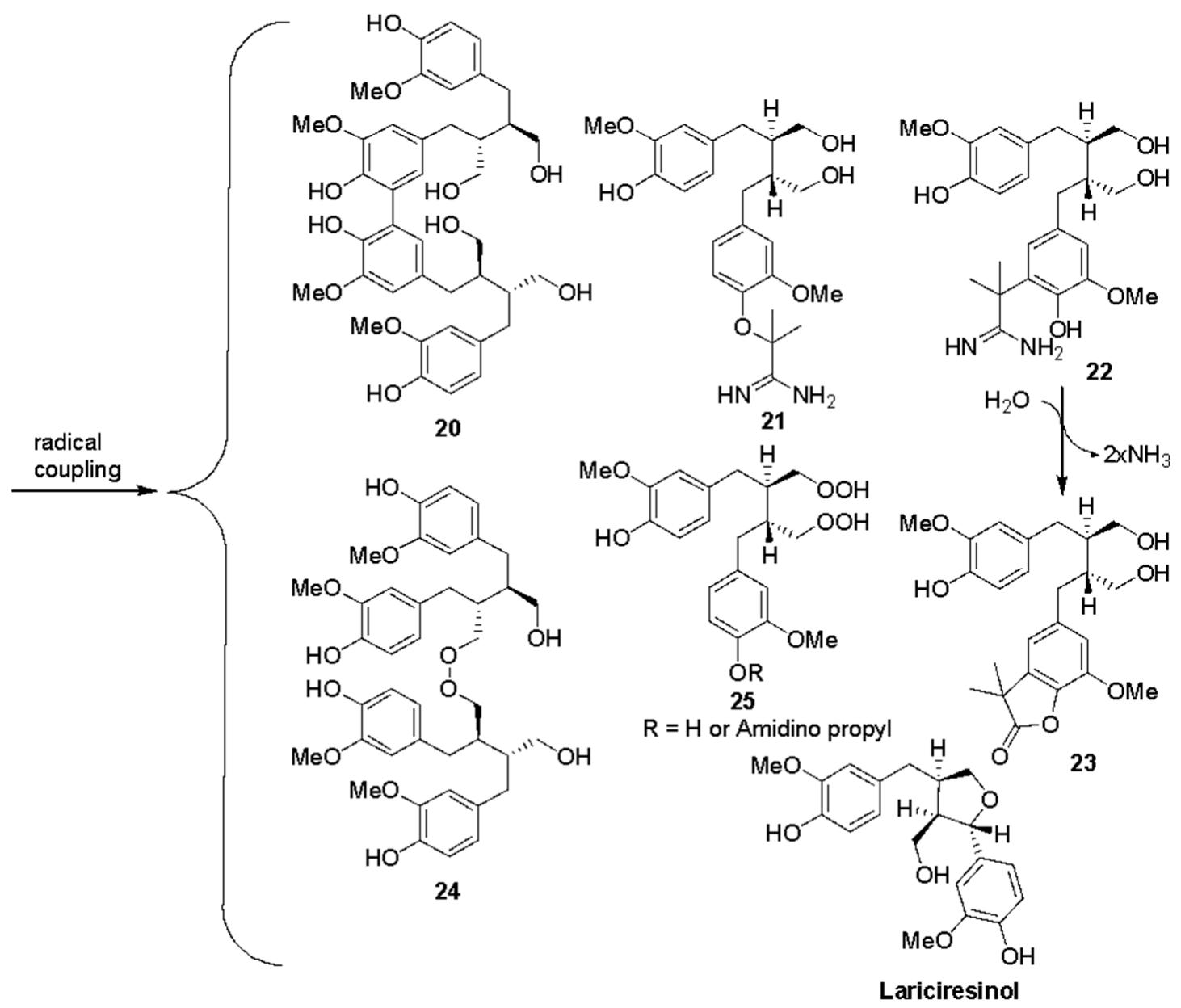

Scheme 12. Oxidation products formed from secoisolariciresinol after 2,2'-Azobis(2-amidinopropan) dihydrochloride (AAPH)-mediated radical scavenging.

\subsection{2,2-Diphenyl-1-picrylhydrazyl (DPPH)}

DPPH is a stable nitrogen centered free radical that is commonly used for antioxidant assays $[64,65]$. It has been vastly used for antioxidant assays on lignans [6,66]. Eklund et al. [51] and Smeds et al. [67] investigated the antioxidant mechanism for the DPPH-initiated radical scavenging of different lignans. Upon radical scavenging, the lignan intermediates underwent further radical abstractions or aryl couplings to form dimers and oligomers by $5-5^{\prime}-$ or $5-O-4^{\prime}$-couplings. An example is shown in Scheme 13 for the reaction between HMR and DPPH. The two major reaction paths, following the initial radical abstraction, were the intramolecular radical coupling forming an aryl-aryl dimer (26), or a second radical abstraction and rearrangement to the lignan oxomatairesinol. Further coupling of the dimeric structure also formed larger oligomers. 


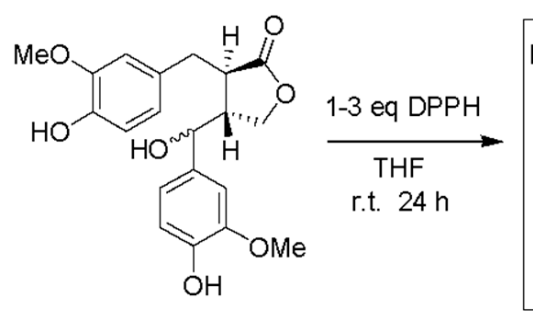

HMR<smiles>COc1cc(C[C@@H]2C(=O)OC[C@H]2[C@H](O)c2cccc(O)c2OC)ccc1O</smiles>

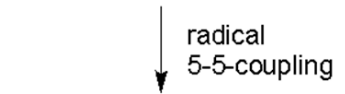<smiles></smiles><smiles>C=C(OC)/C(O)=C(\C)c1cccc(OC)c1C</smiles><smiles>C=C(C)[C@H](O)[C@H]1COC(=O)[C@H]1Cc1ccc(O)c(OC)c1</smiles>

26<smiles>COc1cc(CC2C(=O)OCC2C)ccc1O</smiles><smiles>C[Te]</smiles><smiles>COc1cc(C[C@@H]2C(=O)OC[C@H]2C(=O)c2ccc(O)c(OC)c2)ccc1O</smiles>

Oxomatairesinol

Scheme 13. Reaction products of HMR with the free radical DPPH.

\subsection{2,2,6,6-Tetramethyl-1-piperidinyloxy (TEMPO)}

The free radical organocatalyst TEMPO has been used in combination with a number of different oxidants. For decades it has been used for oxidation of primary and secondary alcohols [164-166]. Surprisingly, TEMPO has not been widely used for the oxidation of lignans. However, a TEMPO-catalyzed oxidation of the benzylic hydroxyl on podophyllotoxin to the corresponding ketone (podophyllotoxone) has been reported (Scheme 14) [68]. Sodium periodate $\left(\mathrm{NaIO}_{4}\right)$ was used as the oxidant in the presence of $\mathrm{NaBr}$ as the co-catalyst.

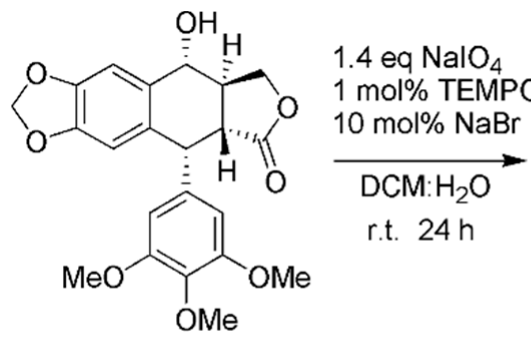

Podophyllotoxin<smiles>COc1cc([C@H]2c3cc4c(cc3C(=O)[C@@H]3COC(=O)[C@@H]32)OCO4)cc(OC)c1OC</smiles>

Podophyllotoxone $60 \%$

Scheme 14. 2,2,6,6-Tetramethyl-1-piperidinyloxy (TEMPO)-mediated oxidation of the benzylic alcohol of podophyllotoxin.

\subsection{Hypervalent Iodine Reagents}

The hypervalent iodine reagents BAIB, PIFA, IBX, DMP, and $\mathrm{NaIO}_{4}$ have been used in numerous studies for mild oxidation of lignan structures. Efficient oxidation of primary and benzylic alcohols into carbonyls, and phenolics into quinones have been reported. In addition, PIFA has been used for arylic coupling to form benzocyclooctadienes. 
2.7.1. [Bis(acetoxy)iodo]benzene (BAIB or PIDA) and [Bis(trifluoroacetoxy)iodo]benzene (PIFA)

Diphyllin was oxidized by BAIB or PIFA through phenolic hydroxyl oxidation and nucleophilic attack to a para-quinone type product (27) (Scheme 15) [69].

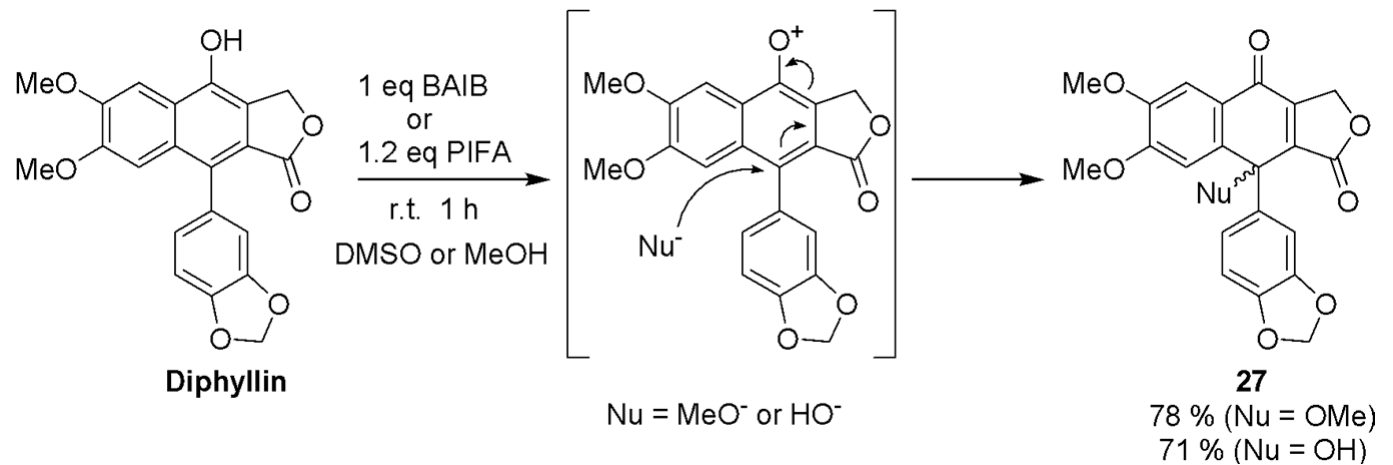

Scheme 15. Bis(trifluoroacetoxy)iodo benzene (PIFA) or Bis(acetoxy)iodo benzene (BAIB)-mediated oxidation of diphyllin.

Lignans have also been ring closed to cyclooctadienes by PIFA in TFE (Scheme 16, upper reaction path). The initial step is believed to be cyclization to a spirodienone intermediate (28) that undergoes rearrangement to the cyclooctadiene product (29). In the cases where a lignan has a para-hydroxyl group, in addition to the cyclooctadiene product, nucleophilic addition at ipso-position to $\mathbf{3 0}$ was reported when using a more nucleophilic solvent such as methanol (Scheme 16, lower reaction path) [70-73]. Other minor products were also formed.
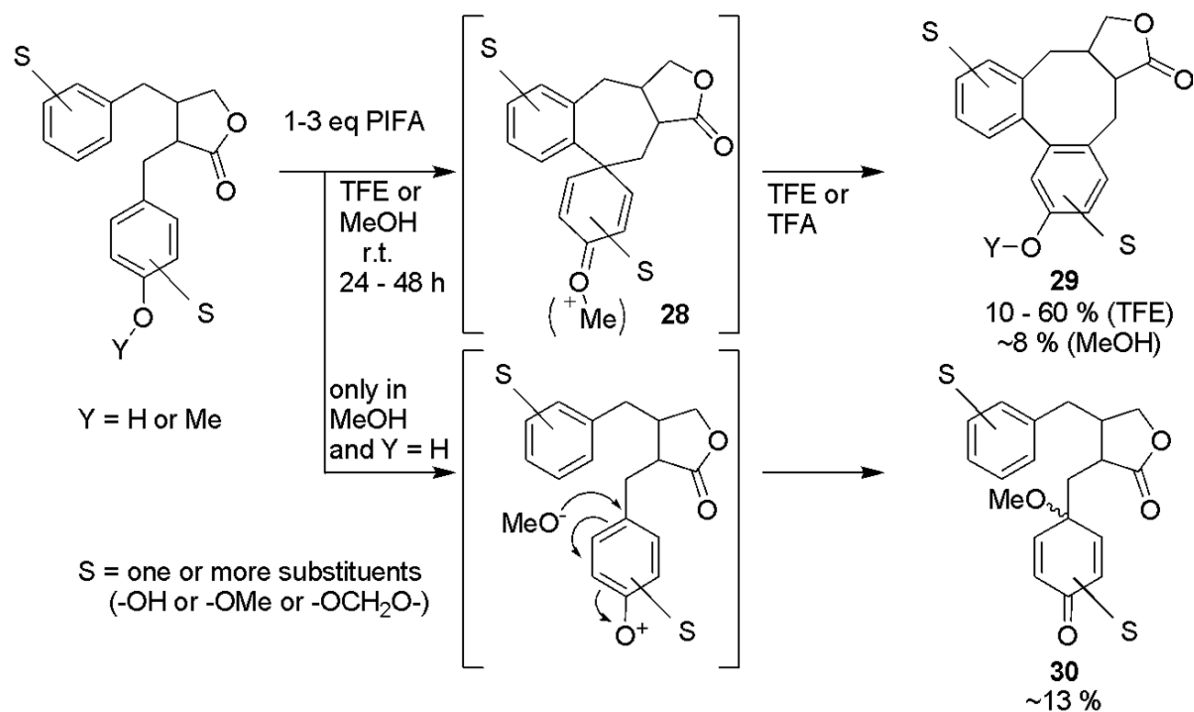

Scheme 16. Lignan oxidation by PIFA in TFE or MeOH. With TFE as the solvent, the major reaction was formation of the cyclooctadiene. In methanol, nucleophilic attack occurred as an additional reaction.

BAIB has also been utilized in the total synthesis of the natural lignan ( \pm )-tanegool. The synthesis started from ferulic acid. Firstly, a diarylcyclobutanediol intermediate (31) was made through a three-step synthesis, involving para-nitro-esterification of the carboxylic acid, light induced [2 +2] coupling, and finally reduction of the para-nitro esters with LAH. This intermediate was then oxidatively ring opened to a di-para-quinone methide (32) by BAIB in TFE and acetone, followed by 5-exo-trig cyclization, by one of the hydroxyls, to 33. The cyclization was stereoselective due to steric hindrance of the bulky aromatic rings. Finally, hydration by addition of water gave ( \pm )-tanegool (Scheme 17) [74]. 


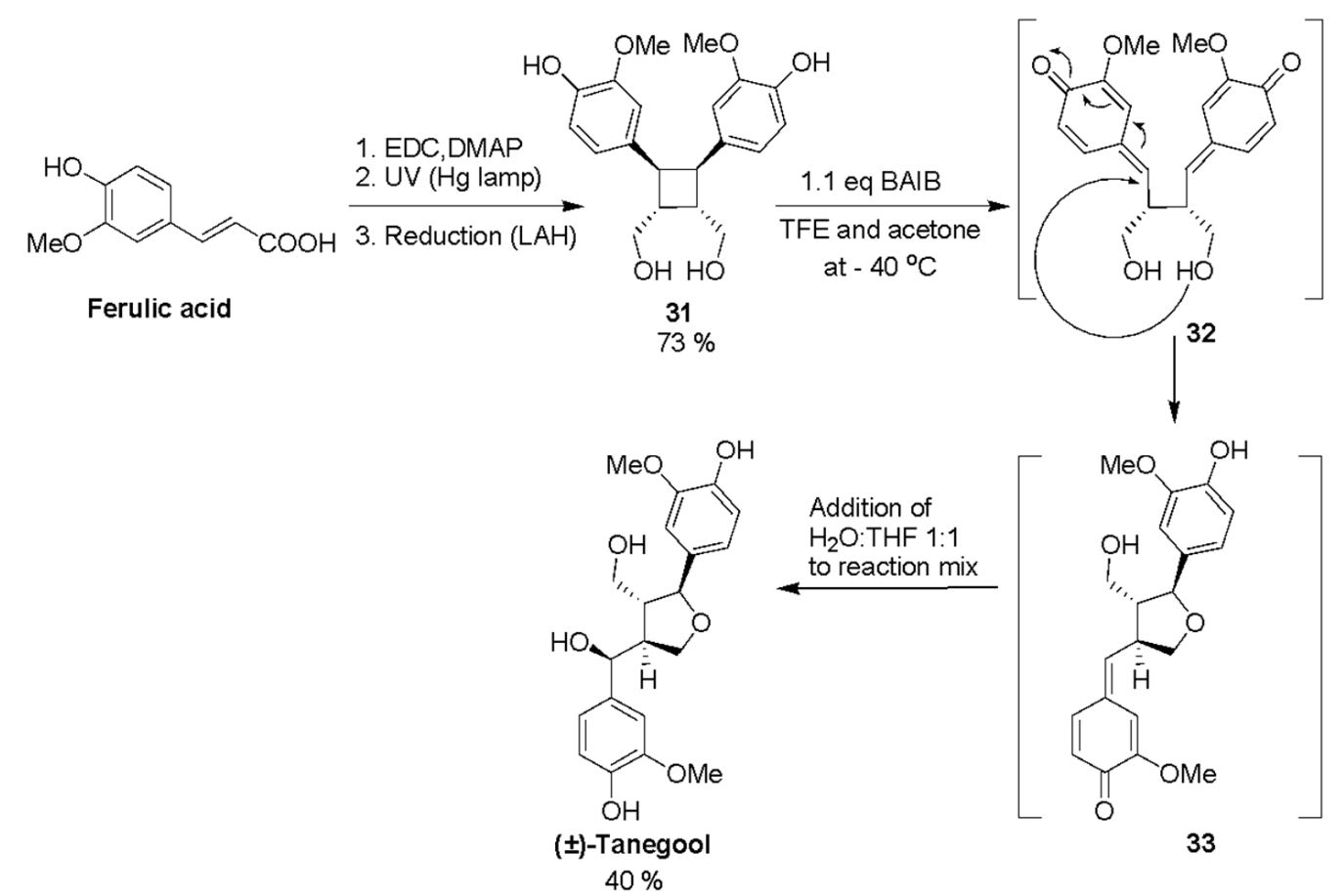

Scheme 17. Total synthesis of $( \pm)$-tanegool involving BAIB mediated oxidative ring opening.

\subsubsection{3-Iodobenzoic Acid (IBX)}

A green and selective demethylation reaction, using IBX as the primary oxidant, has been reported for a number of lignans [75]. The substrates underwent oxidation to an $o$-quinone structure, followed by reduction by sodium hydrosulfite to the catechol products. The reaction was selective towards demethylation of phenolic methoxyl groups, leaving methyl esters intact. Scheme 18 shows the IBX oxidation of a methyl ester norlignan (34). The reaction mixture was acetylated prior to purification through silica gel column chromatography, giving 35 . The same reaction was also successful on the lignans hydroxymatairesinol (product yield $=55 \%$ ), conidendrin (product yield $=70 \%$ ), and lariciresinol (product yield $=40 \%$ ), yielding demethylated products.<smiles>COC(=O)C(/C=C/c1ccc(O)c(OC)c1)Cc1ccc(O)c(OC)c1</smiles>

34
1) 1.2 eq IBX, r.t. $3-5 \mathrm{~h}$ DMC : $\mathrm{H}_{2} \mathrm{O}(9: 1)$ 2) 2.4 eq $\mathrm{Na}_{2} \mathrm{~S}_{2} \mathrm{O}_{4}$

3) $\mathrm{Ac}_{2} \mathrm{O}$, pyridine<smiles>COC(=O)C(/C=C/c1ccc(OC(C)=O)c(OC(C)=O)c1)Cc1ccc(OC(C)=O)c(OC(C)=O)c1</smiles>

Scheme 18. Selective 3-Iodobenzoic Acid (IBX)-mediated demethylation of a norlignan.

When an aliphatic or benzylic alcohol was present, alcohol oxidation to a carbonyl outweighed the demethylation reaction [76]. Scheme 19 shows the selective oxidation of the benzylic alcohol in a synthetic lignan (37) to the corresponding ketone (38). Alternatively, after removal of the protective group, the product was oxidized to the diketone (36). Both of these reactions left the methoxyl groups 
intact [77]. Benzylic alcohol oxidations by IBX have also been reported on other lignans under similar reaction conditions. Both epi-aristoligone and magnolone have been prepared by this method [78,79] (Scheme 19).

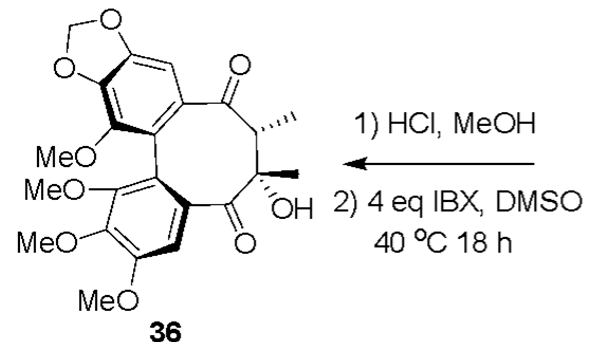

$90 \%$

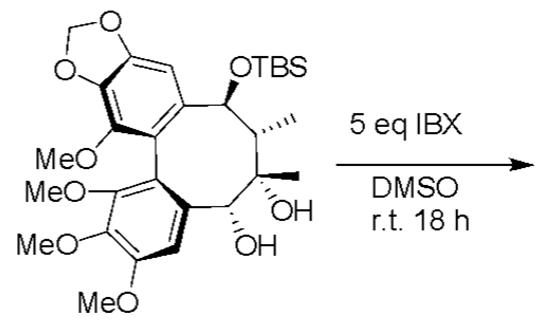

37

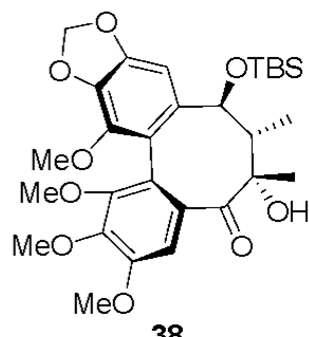<smiles>COc1ccc([C@H]2c3cc(OC)c(OC)cc3C(=O)[C@@H](C)[C@@H]2C)cc1OC</smiles>

(-)-8'-epi-aristoligone $82 \%$<smiles>COc1ccc(C(=O)[C@H]2CO[C@@](C)(c3ccc4c(c3)OCO4)[C@H]2CO)cc1OC</smiles>

$90 \%$

Scheme 19. Oxidation of benzylic alcohols by IBX.

\subsubsection{Dess-Martin Periodinane (DMP)}

DMP has been reported as an agent for mild and selective oxidation of alcohols to aldehydes and ketones. It has a higher solubility compared to its precursor IBX, and lacks the danger of explosion [80].

Oxidation of lignans baring benzylic or aliphatic hydroxyls to the corresponding ketones by DMP have been described for various lignans [81-86]. An example is shown in Scheme 20 for oxidation of isopicrosteganol to the atropisomers of picrosteganone [87]. Scheme 21a shows the oxidation of an aliphatic primary diol (39) with DMP [88]. The reaction quantitatively forms a lactol known as cis-cubebin through subsequent ring closure of the aldehyde. A similar ring closure has been reported by DMP oxidation of a lignan baring a hydroxyl group and a carboxylic acid (40), forming a hydroxy-butyrolactone (41, Scheme 21b) [89].<smiles>COc1cc2c(c(OC)c1OC)-c1cc3c(cc1C[C@H]1C(=O)OC[C@H]1[C@H]2O)OCO3</smiles>

Isopicrosteganol

\section{2 eq Dess-Martin \\ Periodinane

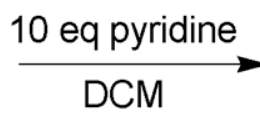

r.t. $10 \mathrm{~min}$<smiles>COc1cc2c(c(OC)c1OC)-c1cc3c(cc1C(=O)[C@@H]1COC(=O)[C@H]1C2)OCO3</smiles>

(士)-Picrosteganone

$92 \%$

Scheme 20. Dess-Martin oxidation of the benzylic alcohol to the ketone. 


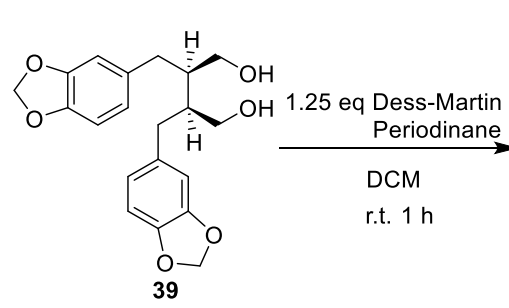

(a)

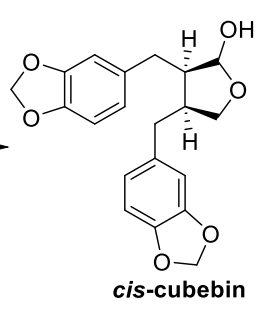

Quantitative yield $9-(R / S)$ in 1:0.3 ratio

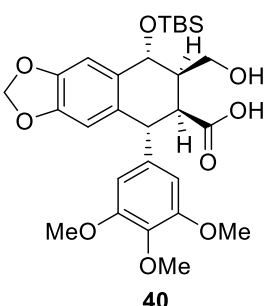

Dess-Martin Periodinane

r.t.

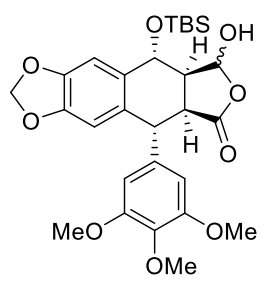

41

$>87 \%$

(b)

Scheme 21. Dess-Martin oxidation of (a) diol 39 to cis-cubebin; (b) hydroxyacid 40 to hydroxybutyrolactone 41.

\subsubsection{Sodium Periodate $\left(\mathrm{NaIO}_{4}\right)$}

In 1955, Adler et al. [90] reported $\mathrm{NaIO}_{4}$ mediated oxidation of guaiacyl or syringyl groups, giving demethylation followed by formation of $o$-quinones. When a syringyl lignan (42) with aliphatic hydroxyls was oxidized with $\mathrm{NaIO}_{4}$, it formed a 5-methoxyl o-quinone structure (43) with an ether bridge to the ortho-position (Scheme 22) [91]. For lignans without aliphatic hydroxyls, as for 44, the $o$-quinone structures were formed without the ether bridge (45, Scheme 23) [92-94].
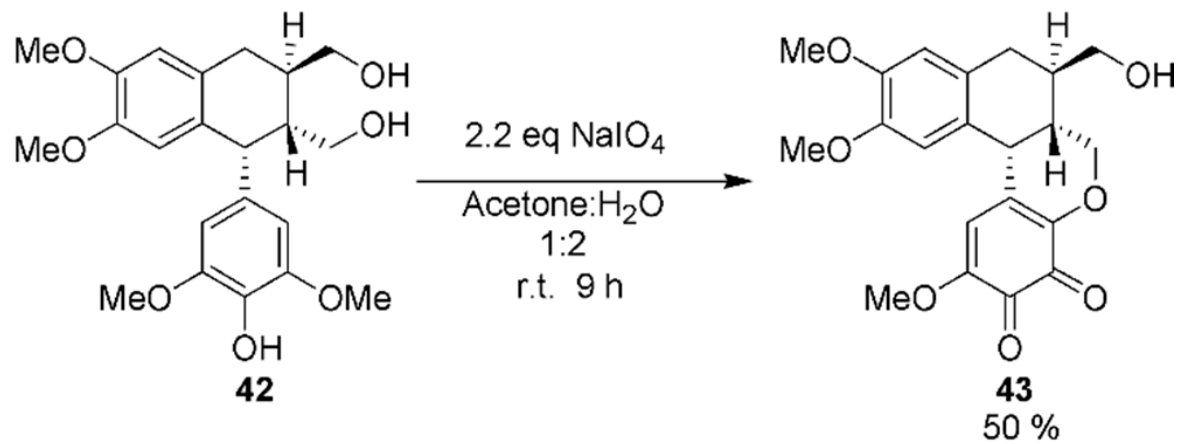

Scheme 22. $\mathrm{NaIO}_{4}$-mediated oxidation to an ether bridged o-quinone structure.

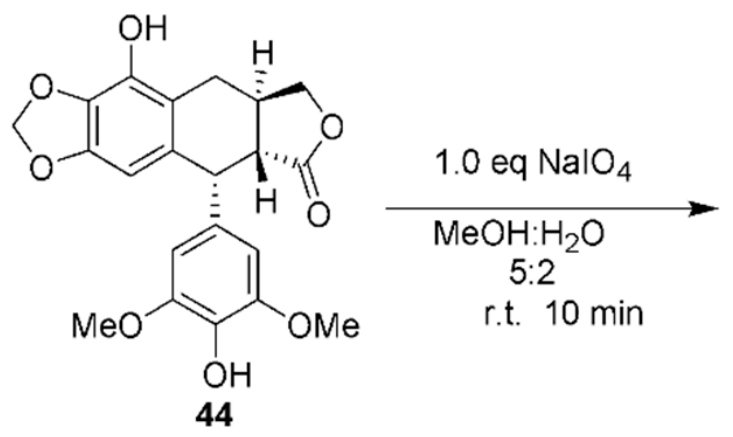<smiles></smiles>

Scheme 23. $\mathrm{NaIO}_{4}$-mediated oxidation of syringyl-lignan forming an o-quinone structure.

In the total synthesis of sylvone, the final steps consisted of the so-called Lemieux-Johnson oxidation. A vicinal diol (47) was formed from an alkene (46) by $\mathrm{OsO}_{4}$, and then a $\mathrm{NaIO}_{4}$-mediated oxidative cleavage of the vicinal diol gave the ketone (sylvone) and formaldehyde (Scheme 24) [95]. Lemieux-Johnson oxidation has been used on other lignans as well, giving ketone products in high yields, as shown in Scheme 24 [96-100]. 

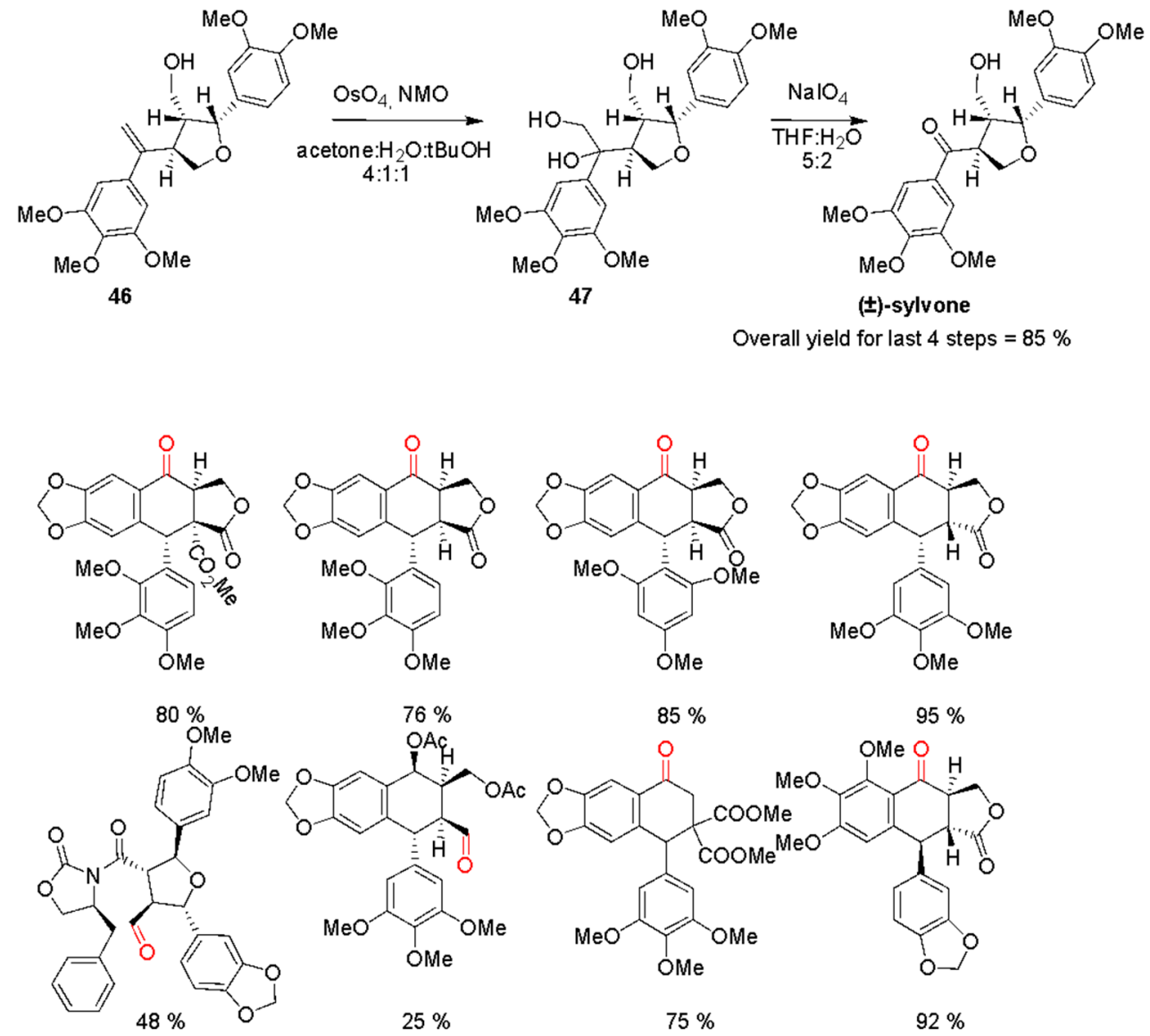

Scheme 24. Lemieux-Johnson oxidation in the synthesis of sylvone (upper). Other lignan structures where the same methodology has been applied (position for oxidation marked in red). The isolated overall yields for both steps are given (lower).

\subsection{N-Bromosuccinimide (NBS)}

The Wohl-Ziegler reaction using NBS and a radical initiator to promote arylic or benzylic bromination has been widely used, and also applied to lignans. Tomioka et al. reported a benzylic bromination of (-)-stegane by NBS in $\mathrm{CCl}_{4}$, using benzoyl peroxide (BPO) as the radical initiator [101]. The formed 4-bromostegane yielded (-)-steganone after hydrolysis in aqueous THF, with an overall yield of $85 \%$ (Scheme 25). By further acetylation, the desired product (-)-steganacin was obtained in $72 \%$ yield. Similar results were also achieved starting from stegane, a stereoisomer of $(+)$-isostegane [35].
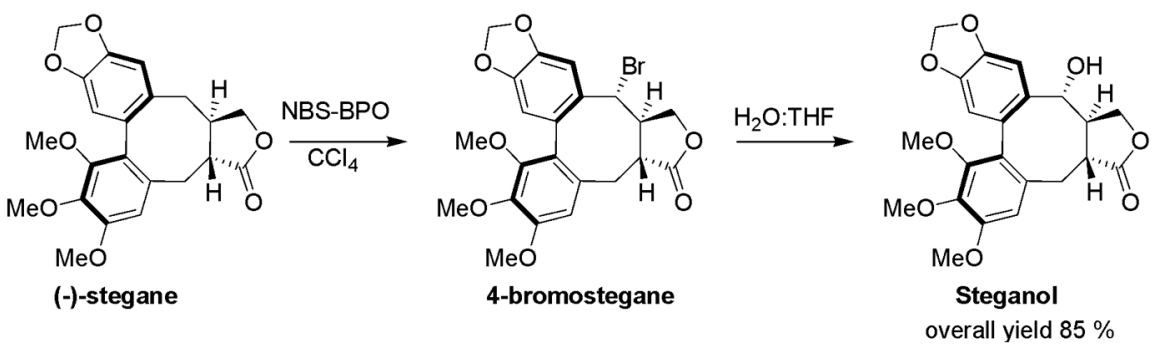

Scheme 25. Wohl-Ziegler bromination of (+)-isostegane followed by hydrolysis to (-)-steganol.

By using a solvent with increased polarity, NBS can also be used to oxidize alcohols to aldehydes and ketones [102]. This has been imposed on a photolytic NBS-mediated oxidation of lignan 48, using dioxane as the solvent, forming a benzylic ketone (49) product in high yield (Scheme 26) [103]. 
The reaction was proposed to proceed through bromination of the benzylic position, followed by hydrolysis by water to a hydroxyl, and finally oxidation to the corresponding ketone.<smiles>CCOC(=O)C1(C(=O)OCC)CCc2cc3c(cc2C1c1cc(OC)c(OC)c(OC)c1)OCO3</smiles>

48

\section{UV-irradiation \\ 4 eq NBS \\ $\stackrel{\text { eq } \mathrm{H}_{2} \mathrm{O}}{\longrightarrow}$ \\ Dioxane \\ r.t. $20 \mathrm{~min}$}<smiles>CCOC(=O)C1(C(=O)OCC)CC(=O)c2cc3c(cc2C1c1cc(OC)c(OC)c(OC)c1)OCO3</smiles>

49

Scheme 26. UV and NBS-mediated formation of the benzylic ketone (49).

When a similar method was applied to deoxypodophyllotoxin by a reaction with NBS in DMF, only arylic bromination occurred (50, Scheme 27) [104]. To get the benzylic ketone, NBS-BPO oxidation in $\mathrm{CCl}_{4}$ followed by hydrolysis was employed. The product epipodophyllotoxine was further oxidized by pyridinium chlorochromate (PCC) to podophyllotoxone. Interestingly, in addition to epipodophyllotoxine, the NBS-mediated reaction also yielded dehydroxypodophyllotoxin through oxidative aromatization [105].

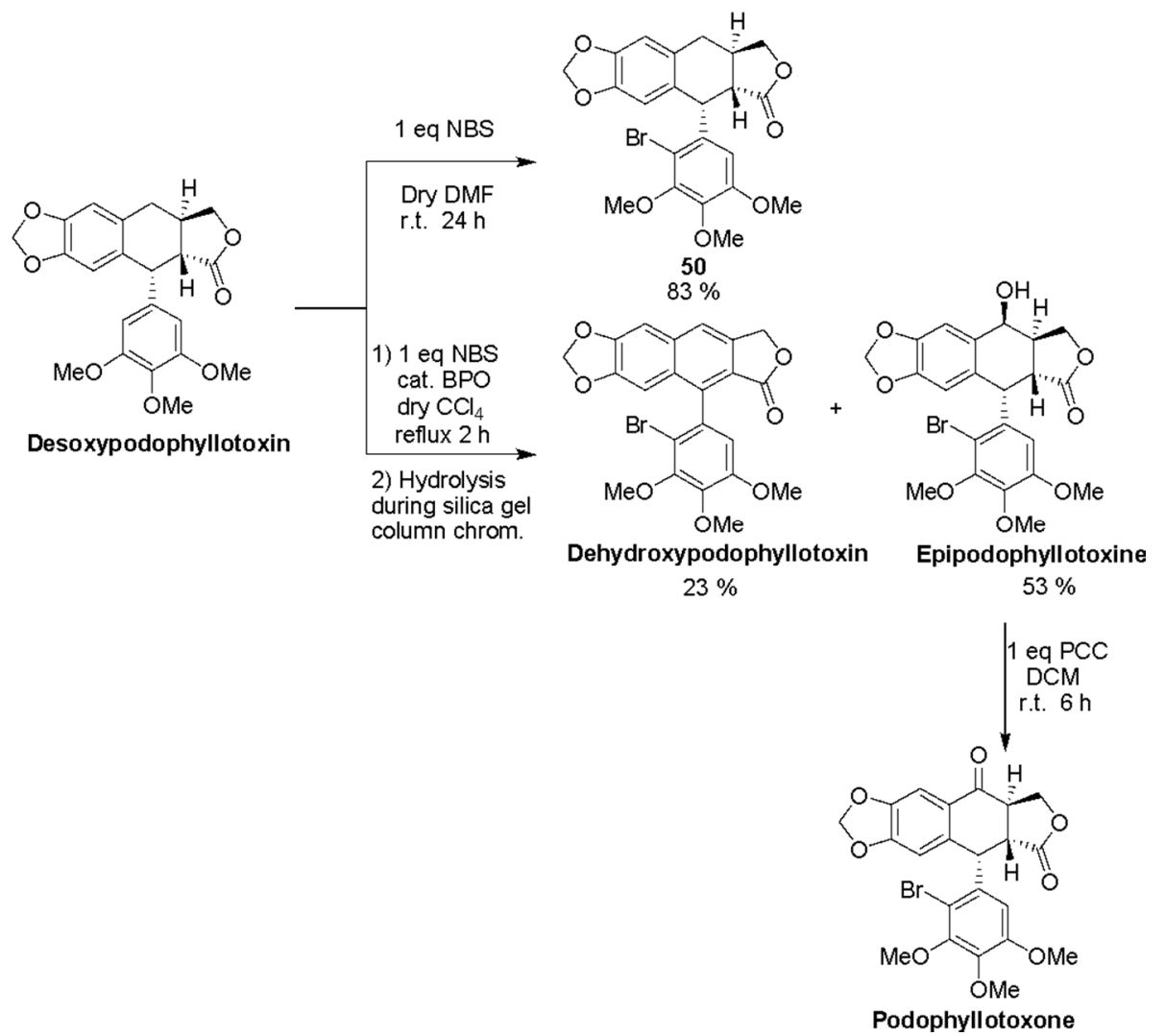

Scheme 27. Reaction of deoxypodophyllotoxin with NBS in DMF and $\mathrm{CCl}_{4}$, and further oxidation of epipodophyllotoxine by PCC to the corresponding ketone (podophyllotoxone).

A similar naphthalene type lignan, known as justicidin B, was formed through NBS-treatment of jatrophan in $\mathrm{CCl}_{4}$ (Scheme 28) $[106,107]$. The reaction includes trans-cis-isomerization, oxidative ring closure, and dehydrogenation. 


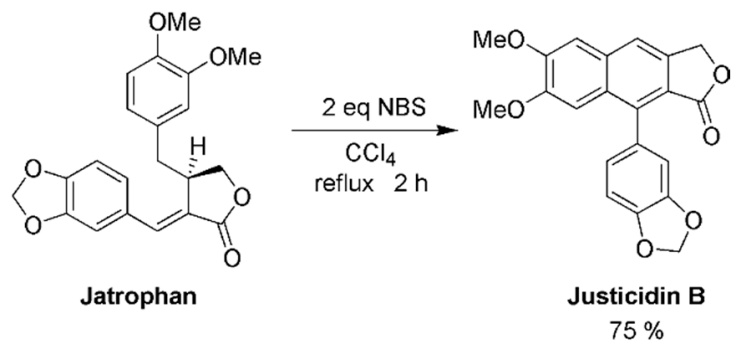

Scheme 28. Synthesis of justicidin B by NBS-oxidation of jetrophan.

\subsection{Dimethyldioxirane (DMDO or DMD)}

A highly selective ring opening of asarinin to a diastereomerically pure product (52) when using DMDO has been reported (Scheme 29) [108]. With one equivalent of DMDO, a selective ring opening was achieved at the C-7 with $R$ configuration, while the other furan ring remained unaltered (51). DMDO was highly reactive towards the substrate, and the reaction needed to be performed at $-20^{\circ} \mathrm{C}$. If more than one equivalent of DMDO was used, the reaction was believed to go through a radical mechanism yielding a mixture of products. However, after acetylation of the product, ring opening of the second furan ring was achieved under the same conditions as previously used, only with a slightly lower yield.

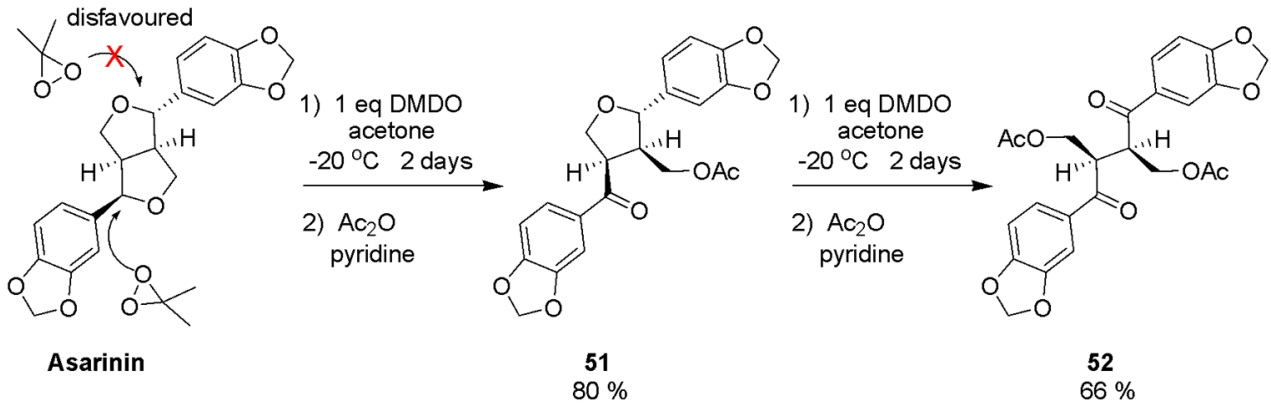

Scheme 29. Selective ring opening of asarinin by DMDO.

\subsection{Nitrobenzene}

Reports from the 1950s and 1960s show oxidative degradation of lignans to vanillin, vanillic acid, and syringaldehyde, using nitrobenzene as the oxidant. Nitrobenzene oxidation of thujaplicatin and dihydroxythujaplicatin, which are lignans found in western red cedar, gave vanillin as the sole product, but only in approximately $2 \%$ yield $[109,110]$. Thujaplicatin methyl ether, with the meta-hydroxyl protected as a methoxyl group, gave around $4 \%$ of both vanillin and syringaldehyde upon nitrobenzene oxidation. Another study systematically oxidized a range of lignans under the following conditions: $180{ }^{\circ} \mathrm{C}, 60 \mathrm{ml}$ of $2 \mathrm{M} \mathrm{NaOH}$ and $8 \mathrm{~mL}$ nitrobenzene per gram of lignan. The reaction time was $2 \mathrm{~h}$. The results are listed in Table 2 [111]. Similarly, nitrobenzene has also been used for the production of vanillin from industrial lignin [167].

Table 2. Results of nitrobenzene-mediated oxidative degradation of lignans.

\begin{tabular}{cccc}
\hline Lignan & Vanillin \% & Vanillic Acid \% & Conversion \% \\
\hline Pinoresinol & 31 & 9 & 81 \\
Lariciresinol & 63 & 5 & 100 \\
Olivil & 83 & 3 & 100 \\
Matairesinol & 15 & 2 & 100 \\
Conidendrin & 1 & - & - \\
Isoolivil & 3 & - & - \\
\hline
\end{tabular}




\section{Metal-Mediated Oxidations}

Oxidation of lignans using metal reagents could be divided into methods which use equimolar amounts or catalytic amounts of the metal oxidant.

Catalytic reactions usually employ transition metals in heterogenous or homogenous conditions and may be sensitive for different functional groups or heteroatoms. Equimolar metal oxidants are widely used for all types of oxidation of lignans, and may involve one-electron oxidations or ionic mechanisms.

\subsection{Chromium (VI) Oxidations}

There are many examples of Chromium (VI) oxidation of benzylic alcohols to ketones in different lignan structures. Acyclic matairesinol derivatives, [112-114], cyclooctadiene structures (53-56) [87,115], and podophyllotoxin derivatives have all been oxidized by $\mathrm{CrO}_{3}$ or $\mathrm{PCC}$ to the corresponding ketone in relatively high yields (60-95\%) [103,105,116,117] (Scheme 30).

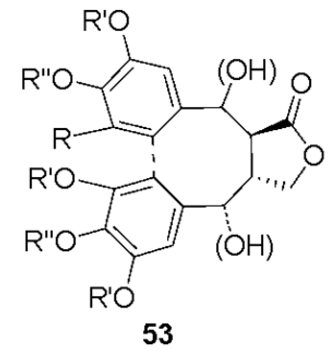<smiles>[R]Oc1cc2c(c([R])c1O[R])-c1c(cc([R])c([R])c1[R])C(O)C1COC(=O)C1C(O)C1COC(=O)C21</smiles>

$\mathrm{R}=\mathrm{OMe}, \mathrm{H} ; \mathrm{R}^{\prime}=\mathrm{R}^{\prime \prime}=$ OMe or $\mathrm{R}^{\prime}+\mathrm{R}^{\prime \prime}=\mathrm{CH}_{2}$
or $\mathrm{R}^{\prime}=\mathrm{OMe}, \mathrm{R}^{\prime \prime}=\mathrm{OBn}$

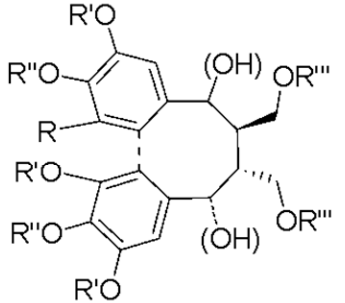

55

$\mathrm{R}^{\prime \prime \prime}=$ OPiv, TMS<smiles>COc1cc(C2c3cc4c(cc3C(O)C3COC(=O)C23)OCO4)cc(OC)c1OC</smiles>

Podophyllotoxin

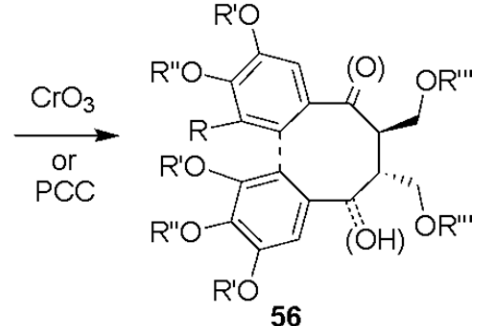

$75-95 \%$

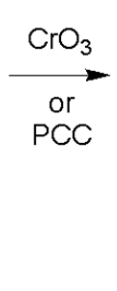<smiles>COc1cc(C2c3cc4c(cc3C(=O)C3COC(=O)C32)OCO4)cc(OC)c1OC</smiles>

$76-90 \%$

Scheme 30. Oxidation of the benzylic alcohol to the corresponding ketone by $\mathrm{Cr}(\mathrm{VI})$ oxidants. The dotted line corresponds to either the existence of the bond or the absence of the bond.

$\mathrm{Cr}(\mathrm{VI})$ mediated oxidation of primary alcohols in the lignan structures (57) has also been performed. Oxidation by PCC or $\mathrm{CrO}_{3}$ led to lactones and carboxylic acids (58 and 59) [118-120] (Scheme 31).

There are no literature examples where chromium (VI) oxidants have successfully been used for oxidation of lignans in the presence of free phenolic groups. Therefore, it can be concluded that chromium mediated oxidations cannot be performed when phenolic groups are present in the structure. 
<smiles>[R]c1cc(C2c3c(cc(OC)c(OC)c3[R])CC(C([R])([R])OC)C2CO)cc(OC)c1OC</smiles>

57

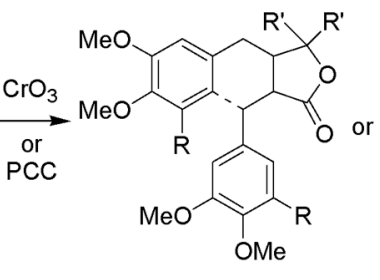

58<smiles>[R]c1cc(C2c3c(cc(OC)c(OC)c3[R])CC(C([R])([R])OC)C2C(=O)O)cc(OC)c1OC</smiles>

59

$\mathrm{R}=\mathrm{OMe}, \mathrm{R}^{\prime}=\mathrm{H} \quad 40 \%$

Scheme 31. Oxidation of the primary alcohols by $\mathrm{Cr}(\mathrm{VI})$ oxidants. The dotted line corresponds to either the existence of the bond or the absence of the bond.

\subsection{Palladium and Gold Mediated Oxidations}

Oxidation of benzylic alcohols in the presence of free phenolic groups has been achieved by transition metal catalysis. Hydroxymatairesinol (HMR) has been shown to undergo catalytic dehydrogenation in mild conditions, using palladium on different supporting materials [121] (Scheme 32). The major oxidation product was oxomatairesinol, however, hydrogen formed during the dehydrogenation partially reacted with HMR by hydrogenolysis to give a significant amount of matairesinol as a side product. Later on, it was shown that the same transformation could also be performed using gold as a catalyst [121]. This method was much more selective towards oxomatairesinol [123] and showed faster conversion in the presence of oxygen [124-126]. It is noteworthy that one diastereomer of HMR gave oxomatairesinol much more selectively and with higher conversion rates, but some conidendrin was also formed as a side product depending on the conditions of the reaction.<smiles>COc1cc(CC2C(=O)OC[C@H]2Cc2ccccc2O)ccc1O</smiles>

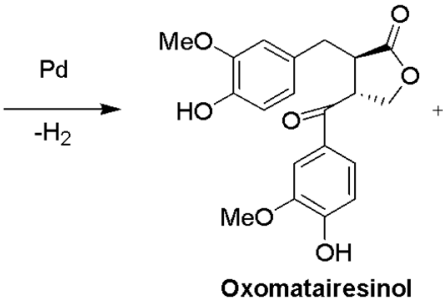<smiles>COc1cc(CC2COC(=O)C2Cc2ccc(O)c(OC)c2)ccc1O</smiles><smiles>COc1cc(CC2C(=O)OC[C@H]2Cc2ccc(O)c(OC)c2)ccc1O</smiles>

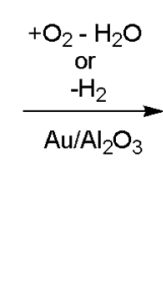<smiles>COc1cc(C2C(=O)C(c3ccc(O)c(OC)c3)[C@@H]3COC(=O)C23)ccc1O</smiles><smiles>COc1cc([C@@H]2c3cc(O)c(OC)cc3C[C@@H]3C(=O)OC[C@@H]32)ccc1O</smiles>

Scheme 32. Palladium and gold catalyzed oxidation (dehydrogenation) of hydroxymatairesinol.

\subsection{Molybdenium Mediated Oxidations}

Hydroxylation at the $\alpha$-position of butyrolactone lignans $(\mathbf{6 0})$ has been performed directly on the deprotonated ester by molecular oxygen [127,128]. However, this reaction proceeded much faster and with better selectivity when molybdenum reagents were used. For this purpose, oxodiperoxymolybdenum (pyridine) (hexamethylphosphoric triamide), MoO5.Py·HMPA(MoOPH), also known as Vedejs' reagent was used [113,129-131]. The stereoselectivity of the oxidation was very much dependent on the base and the conditions used for the deprotonation. For example, if KHMDS was used, the diastereomeric excess of one isomer was just $11 \%[113,130]$. At the same time, when KHMDS was used together with 18-crown-6, the selectivity raised to 64-99\% [130,131] (Scheme 33). 

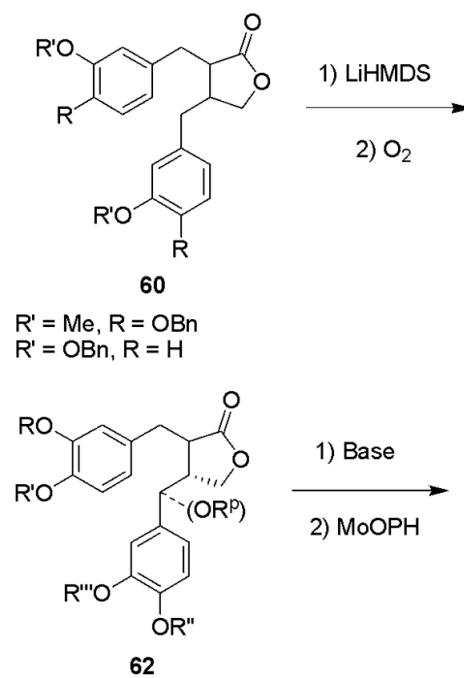

$\mathrm{R}+\mathrm{R}^{\prime}=\mathrm{CH}_{2}, \mathrm{R}^{\prime \prime}=\mathrm{R}^{\prime \prime}=\mathrm{Me}$, no OR<smiles>[R]Oc1ccc(CC2(Cc3ccc([R])c([R])c3)COC2O)cc1</smiles>

61

$24-40 \%$

$\mathrm{R}+\mathrm{R}^{\prime}=\mathrm{CH}_{2}, \mathrm{R}^{\prime \prime}=\mathrm{R}^{\prime \prime}=\mathrm{Me}, \mathrm{R}^{\mathrm{P}}=\mathrm{TMS}, \mathrm{MOM}, \mathrm{Ac}, \mathrm{Me}$

$R=R^{\prime \prime}=M e, R^{\prime}=R^{\prime \prime}=B n, R^{p}=T M S$ or no $O^{p}$

Base $=$ LiHMDS, KHMDS, LDA

Scheme 33. Molybdenum catalyzed $\alpha$-hydroxylation of butyrolactone lignans. The dotted line corresponds to either the existence of the bond or the absence of the bond.

Molybdenum reagents have also been used for the preparation of 2-2'-cyclolignan structures. Oxidative coupling of two aryls was performed with molybdenum pentachloride $\left(\mathrm{MoCl}_{5}\right)[132,133]$. The formation of the cyclooctadiene structure proceeded with excellent yields when the substrates were non-functionalized aliphatics, but the yields decreased dramatically with increasing degree of functionalization (Scheme 34).<smiles>[R]Cc1ccc(CC([R])C([R])Cc2cc([R])c([R])c([R])c2[R])cc1OC</smiles>

$\mathrm{R}=\mathrm{H}, \mathrm{R}^{\prime}, \mathrm{R}^{\prime \prime}, \mathrm{R}^{\prime \prime \prime}, \mathrm{R}^{\prime \prime \prime}=$ OMe or $\mathrm{H}$

$R=M e, R^{\prime}=R^{\prime \prime \prime}=H, R^{\prime \prime}=R^{\prime \prime \prime}=O M e$<smiles>COc1ccc(CC2COC(=O)C2Cc2ccc(OC)c(OC)c2)cc1OC</smiles>

66<smiles>[R]c1c([R])c([R])c2c(c1[R])CC([R])C([R])Cc1cc(OC)c(OC)cc1-2</smiles>

$76-89 \%$

$30 \%$

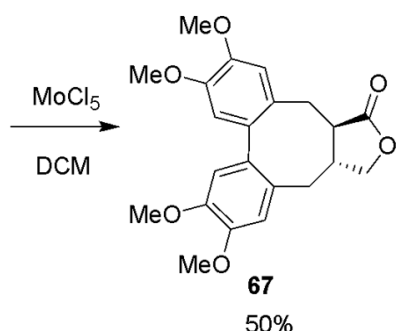

Scheme 34. Ar-Ar oxidative coupling by $\mathrm{MoCl}_{5}$.

\subsection{Vanadium, Thallium and Ruthenium Oxidations}

Oxidative coupling has also been reported using V, Tl, and Ru. Vanadinum oxofluoride in the presence of trifluoroacetic acid has shown good selectivity for the Ar-Ar oxidative coupling, forming the cyclooctadiene lignan structure Isostegnane in high yield [134] (Scheme 35). 


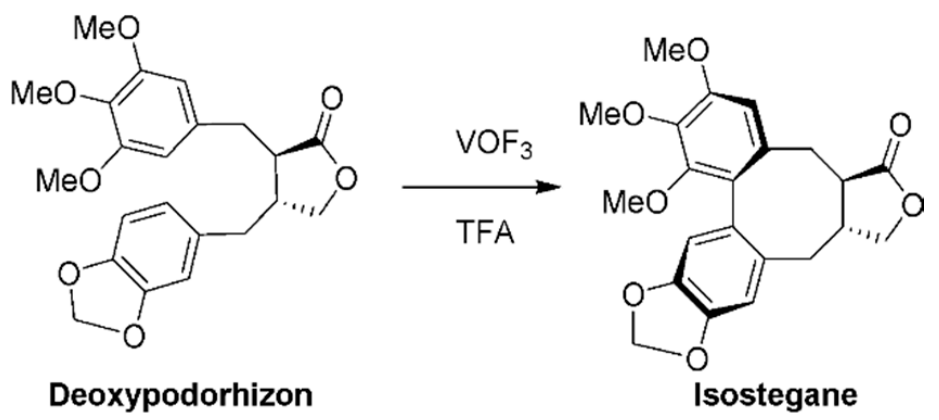

$65-70 \%$

Scheme 35. Ar-Ar oxidative coupling by $\mathrm{VOF}_{3}$.

Later it was also shown that thallium oxide $\left(\mathrm{Tl}_{2} \mathrm{O}_{3}\right)$ or ruthenium oxide $\left(\mathrm{RuO}_{2}\right)$ also work well as oxidants in this reaction $[135,136]$. In fact, the reactions with ruthenium oxide showed higher yields than reactions with thallium oxide, and vanadium oxofluoride reactions showed slightly lower yields in the vast majority of the reported reactions [137-141]. High stereoselectivity was observed in most cases (Scheme 36).

In many of these reactions, $2-7^{\prime}$-cyclolignans (74) and (77) were formed as minor products by oxidation of the benzylic positions [140,142-144] (Scheme 37).

Interestingly, these reactions also proceeded in the presence of a free phenolic group. Yields up to $90 \%$ of $\mathbf{7 9}$ were obtained with matairesinol derivatives (78) [137,144-146] (Scheme 38).

It has also been reported by Planchenault et al. $[145,147]$ that some metal oxidants other than Mo, $\mathrm{V}, \mathrm{Ru}$, and $\mathrm{Tl}$, such as $\mathrm{Mn}(\mathrm{OAc})_{3}, \mathrm{Ce}(\mathrm{OH})_{4}, \mathrm{Re}_{2} \mathrm{O}_{7}, \mathrm{Fe}(\mathrm{OH})(\mathrm{OAc})_{2}, \mathrm{Co}_{3} \mathrm{O}_{4}, \mathrm{Ag}\left(\mathrm{OCOCF}_{3}\right)_{2}, \mathrm{CrO}_{3}, \mathrm{IrO}_{2}$, $\operatorname{Pr}_{6} \mathrm{O}_{11}, \mathrm{SeO}_{2}, \mathrm{TeO}_{2}$ etc., are possible to use for high yield preparations of cyclooctadiene-lignans.<smiles>COc1cc(CC2COC(=O)C2Cc2cc(OC)c(OC)c(OC)c2)cc(OC)c1OC</smiles>

68

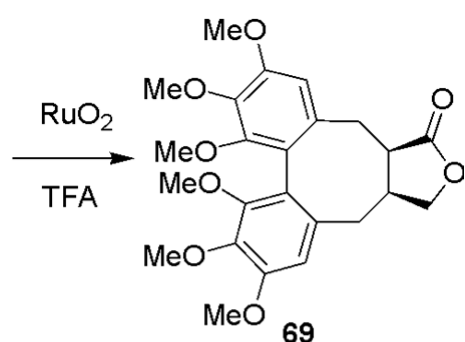

$90-95 \%$<smiles>[R]c1c(C[C@@H]2COC(=O)[C@@H]2Cc2ccc(OC)c(OC)c2[R])ccc(OC)c1OC</smiles>

70<smiles></smiles>

71

$75-79 \%$ $\sim 50 \%$

Scheme 36. Ar-Ar oxidative coupling by $\mathrm{VOF}_{3}, \mathrm{RuO}_{2}$, or $\mathrm{Tl}_{2} \mathrm{O}_{3}$. 

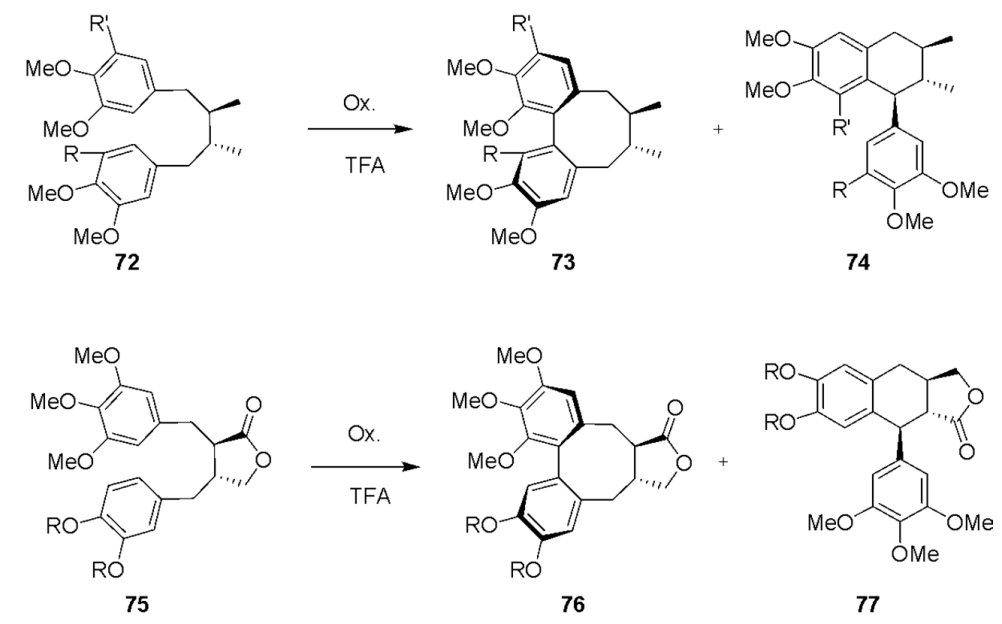

$\mathrm{R}=\mathrm{Me}$ or $\mathrm{R}+\mathrm{R}=\mathrm{CH}_{2}$

Scheme 37. $\mathrm{Ru}, \mathrm{Tl}$, and $\mathrm{V}$ mediated oxidative cyclizations, forming 2-2' and 2-7'cyclolignans.

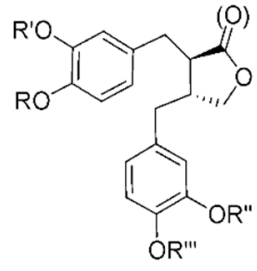

78

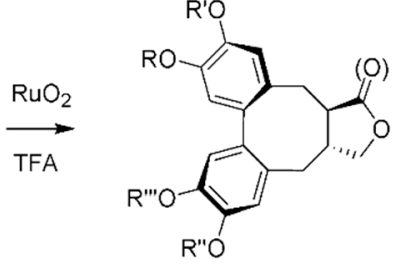

79

$84-90 \%$

Scheme 38. Oxidative coupling of matairesinol derivatives in the presence of free phenolic groups.

\subsection{Methyl Trioxo-Rhenium (MTO) Catalyzed Oxidations}

MTO catalyzed oxidations are interesting because of the diversity of possible transformations. For example, podophyllotoxin and related structures (81) were oxidized to quinone structures (80 and $\mathbf{8 2}$ ) by MTO [148] (Scheme 39). The reaction proceeded via demethylation, hydroxylations, and at the same time, the benzylic alcohol was oxidized.<smiles>COc1cc(C2c3cc4c(cc3C(O)C2COC(=O)O)COCO4)cc(OC)c1OC</smiles>

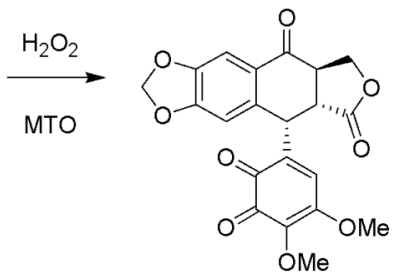

80

up to $71 \%$<smiles>COc1cc2c(cc1OC)[C@H](c1cc(OC)c(OC)c(OC)c1)[C@H](C)[C@H](C)C2</smiles>

81

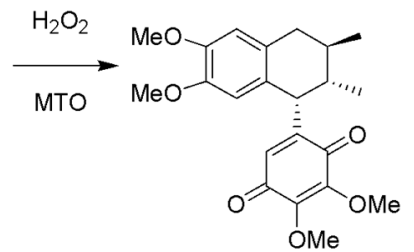

82

up to $36 \%$

Scheme 39. Oxidation of podophyllotoxin and related structures by Methyl Trioxo-Rhenium (MTO). 
When asaranin and sesaminin were treated with MTO in similar conditions, the reaction resulted in cleavage at the benzylic position to yield lactones (83 and 84) [149]. (Scheme 40).

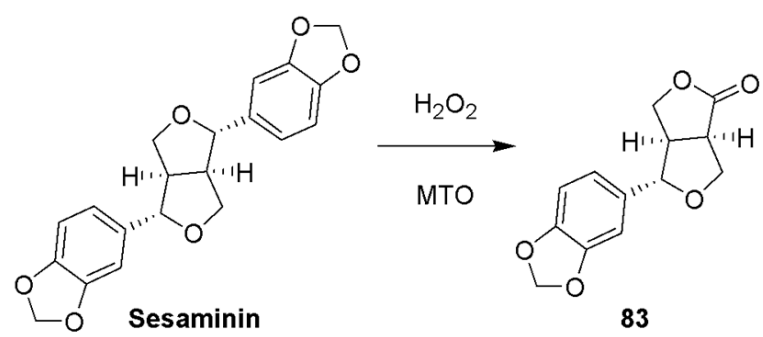

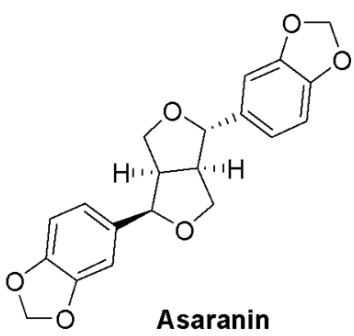<smiles>O=C1OC[C@H]2CO[C@H](c3ccc4c(c3)OCO4)[C@H]12</smiles>

$85-89 \%$

Scheme 40. Oxidation of asaranin and sesaminin with MTO.

MTO catalyzed reactions with lariciresinol, matairesinol and hydroxymatairesinol resulted in multiple benzylic hydroxylations, demethylations, oxidations, and cleavage of water [150] (Scheme 41, structures 85-90).

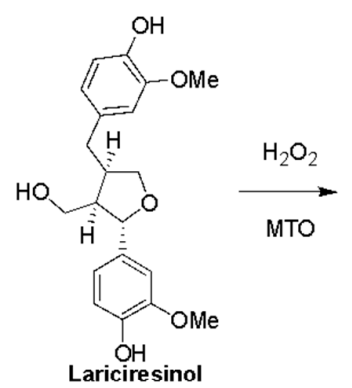<smiles>COc1cc(C[C@H]2CO[C@](O)(c3ccc(O)c(OC)c3)[C@H]2CO)ccc1O</smiles><smiles>COc1cc(C[C@@H]2COC(=O)[C@H]2Cc2ccc(O)c(OC)c2)ccc1O</smiles>

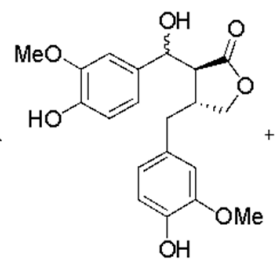

7'-hydroxymatairesinol<smiles>COc1cc(CC2C(=O)OCC2Cc2ccc(O)c(O)c2)ccc1O</smiles>

86<smiles>COc1cc(CC2C(=O)OC[C@H]2Cc2ccc(O)c(OC)c2)ccc1O</smiles>

Hydroxymatairesinol

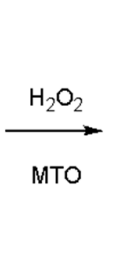

MTO

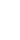<smiles>COc1cc(C(=O)[C@@H]2COC(=O)[C@@H]2[C@@H](O)c2ccc(O)c(OC)c2)ccc1O</smiles>

88

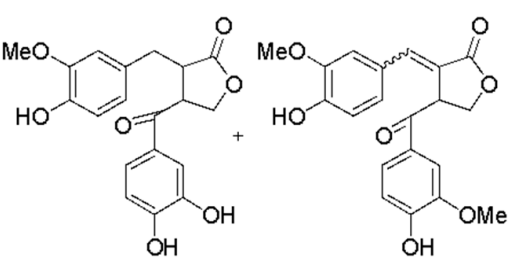

89

90

Scheme 41. Oxidation of lariciresinol, matairesinol, and hydroxymatairesinol by MTO (major products shown). 


\subsection{Other Metal Mediated Lignan Oxidations}

Oxidative acetoxylation of matairesinol derivatives $\mathbf{9 1}$ and $\mathbf{9 3}$ has been accomplished using lead acetate [151] (Scheme 42). In the reactions of the trans-butyrolactone derivatives (91), one diastereomer of the 7-acetoxy product (92) was formed in high yield (60-73\%). In the reaction of the cis lactone (93) in the same conditions, the reaction resulted in a mixture of the 7-acetoxy product (94) and the 2'-7-cyclolignan (95).
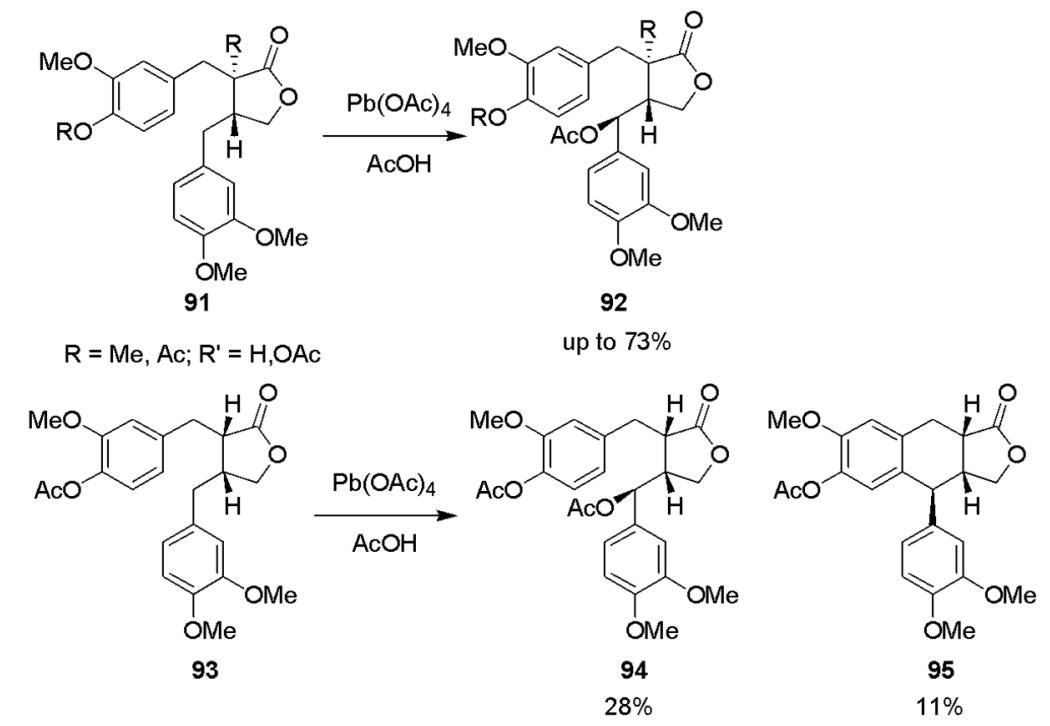

up to $73 \%$

Scheme 42. Lead acetate acetoxylation of matairesinol derivatives.

In addition to molybdenum initiated $\alpha$-hydroxylation of esters, cerium trichloride catalyzed $\alpha$-hydroxylation has also been reported [152]. This method did not require deprotonation of the $\alpha$-position. Coordination of cerium to two $\alpha$-carbonyls directed the position of the oxidation. (Scheme 43).

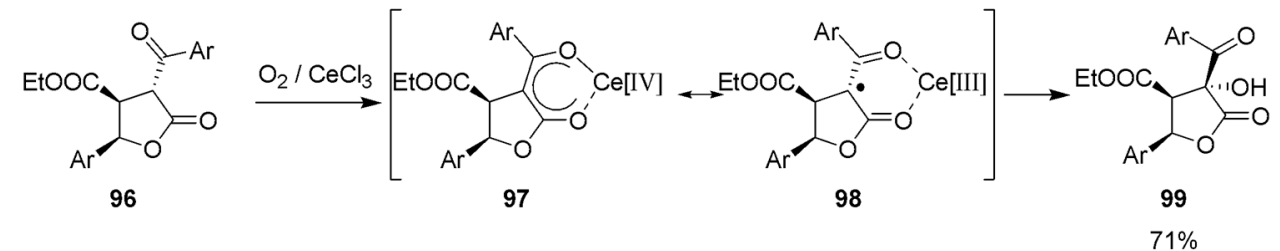

Scheme 43. Cerium trichloride mediated $\alpha$-hydroxylation.

\section{Other Oxidation Methods}

\subsection{Enzymatic Oxidations}

Although enzymatic oxidations have mostly been studied for elucidation of biosynthetic routes for many lignans, some attempts for targeted oxidations in vitro have been reported.

Laccases are copper-containing oxidases which have been used in, among others, wood, pulp, and paper industries [168]. They play a key role in the dimerization of 4-hydroxycinnamic acids in the biosyntheses of natural lignans [22,169]. Lignans have also been used as substrates in laccase activity studies $[170,171]$. Laccase oxidations of lignans baring guaiacyl groups have led to efficient polymerization [172-174]. The mechanism is believed to involve hydrogen atom abstraction to form phenoxyl radicals, which then undergo intermolecular radical couplings [175].

Peroxidases are another group of oxidases which are also involved in the biosynthesis of lignans through $\beta-\beta$ coupling of two phenylpropanoid units $[22,169,176,177]$. They typically use hydrogen 
peroxide as cofactor in the oxidation reactions. A range of different peroxidases has been used for selective ring closure of butyrolactone lignans (ex. 100) with up to quantitative yields of the aryltetralin product (ex. 101) (Scheme 44). The reactions were performed with both immobilized cell cultures and freely suspended plant cell cultures, and in absence of foreign hydrogen peroxide. Although the reaction worked also in hexane, quantitative ring closure only occurred when the reaction was done in B5 medium $[153,154]$. A similar reaction, but with $\mathrm{H}_{2} \mathrm{O}_{2}$ as a cofactor and ethanol as solvent, has also been reported on the same lignan [155].
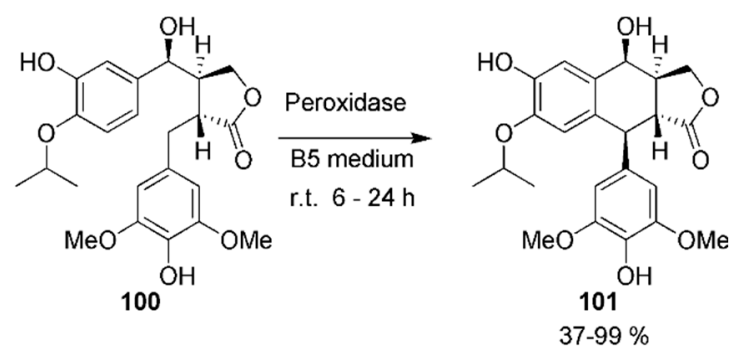

Scheme 44. Enzymatic, peroxidase-mediated ring closure.

A study of 4-O-5 units in softwood lignin used pinoresinol, among others, as a lignin model compound. A pinoresinol dimer (102) coupled through a 4-O-5 bond, was synthesized using horseradish peroxidase (HRP) and a hydrogen peroxide-urea complex (Scheme 45) [156]. Although sufficient for the study, the isolated yield was very low.

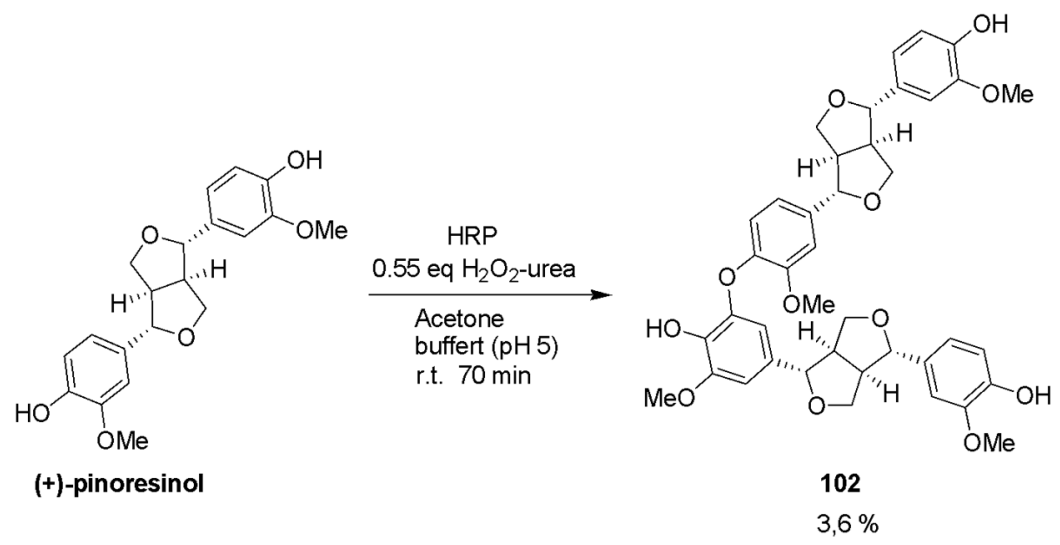

Scheme 45. Peroxidase and $\mathrm{H}_{2} \mathrm{O}_{2}$ - mediated 4-O-5-coupling.

In the biosynthesis of matairesinol, secoisolariciresinol is oxidized by an enzyme known as secoisolariciresinol dehydrogenase (SDH) $[178,179]$. The reaction proceeds through an oxidative ring closure of the diol to a lactol, and further oxidation to the lactone. In a study on the mode of catalysis of $\mathrm{SDH}$, the reaction was done in vitro, in a $5 \mathrm{mM}$ scale, using isolated $\mathrm{SDH}$ and $\mathrm{NAD}^{+}$in a Tris- $\mathrm{HCl}$ buffer (Scheme 46) [157].

Enzymatic oxidation of sesamin has been studied in vitro, using yeast cells expressing some of the enzymes found in sesame seeds [158]. Yeast strains containing a combination of a P450 enzyme (CYP92B14) and Sesamum indicum cytochrome P450 oxidoreductase 1 (CPR1) in a synthetic defined (SD) medium gave, via oxidation and rearrangement, sesaminol and sesamolin (Scheme 47), two lignans found in sesame seeds.

Escherichia coli expressing human hepatic enzymes (CYP) have been used for the bioconversion of deoxypodophyllotoxin into epipodophyllotoxin (Scheme 48) [159]. The objective of the study was to investigate a possible route for industrial production of epipodophyllotoxin, which is a valuable precursor for the pharmaceutical industry. High conversions were achieved, but the reactions were done 
in scales up to only $0.5 \mu$ mols. The high cost of up scaling was presented as the bottleneck that needed to be tackled before a possible industrial production. A large scale isolation of deoxypodophyllotoxin, from wild chervil (Anthriscus sylvestris), had already been accomplished [180].

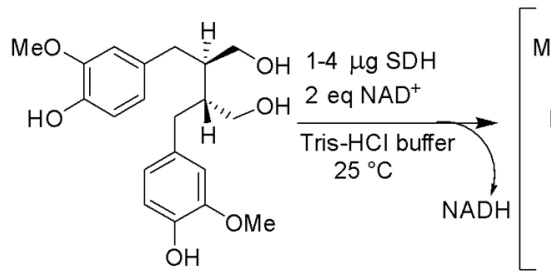

secoisolariciresinol<smiles>COc1cc(CC2COC3C(Cc4cccc(O)c4)OCC23)ccc1O</smiles>

103<smiles>CCCCOc1ccc(CC2C(=O)OC2Cc2ccc(O)c(OC)c2)cc1O</smiles>

matairesinol

$3.5 \mathrm{pmol} \mathrm{min}{ }^{-1} \mu \mathrm{g}^{-1} \mathrm{SDH}$

Scheme 46. Enzymatic transformation of secolariciresinol into matairesinol.

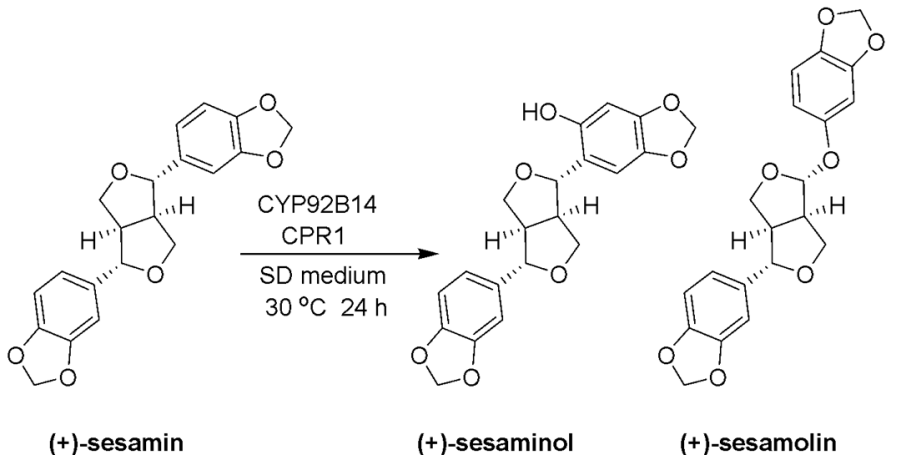

Scheme 47. Enzymatic transformation of sesamin into sesaminol and sesamolin.

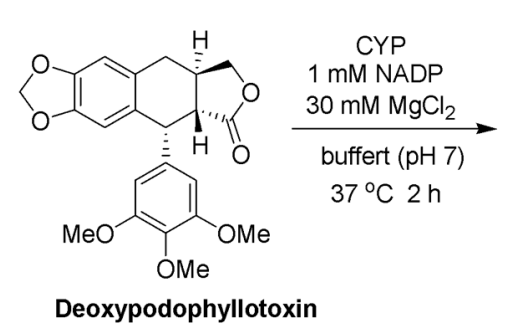

Scheme 48. Enzymatic bioconversion of deoxypodophyllotoxin into epipodophyllotoxin.

\subsection{Electrochemical Oxidations}

An acetoxy lignan (104) (Scheme 49) has been electrochemically oxidized to an o-quinone (105) at a constant anode potential of $0.725 \mathrm{~V}$ using a platinum gauze working electrode, a platinum wire counter electrode and an $\mathrm{Ag} / \mathrm{Ag}^{+}$reference electrode. The electrolyte was a solution of $0.01 \mathrm{M}$ tetrabutylammonium tetraboroflourate in acetonitrile, with solid potassium carbonate as a buffer. The product was not isolated, but further reduced to a catechol, which was isolated and characterized [160].

Dibenzocyclooctadienes have been synthesized by electrochemical oxidation of butyrolactone lignans (106) (Scheme 50). A platinum working electrode, a platinum counter electrode, a Ag/AgBr, $\mathrm{Et}_{4} \mathrm{NBr}$ reference electrode, and a $0.1 \mathrm{M} \mathrm{Et}_{4} \mathrm{NClO}_{4}-\mathrm{CH}_{3} \mathrm{CN}$ supporting electrolyte was used. The products (107) were obtained in high yields, more than $80 \%$ in both cases [161].

The lignan hibalactone has been electrochemically oxidized using voltammetry with a three-electrode system, consisting of a glassy carbon working electrode, a platinum counter electrode, 
and a $\mathrm{Ag} / \mathrm{AgCl}$ counter electrode. The lignan showed a single quasi-reversible electro-oxidation, with the alkene bonded to the lactone ring being the most probable site of oxidation [181]. The lignans epi-guaiacin, guaiacin, verrucosin, and nectandrin B have been isolated from Iryanthera juruensis fruits and electrochemically oxidized during an investigation of their antioxidative properties (Figure 1). A glassy carbon working electrode, a carbon counter electrode, and a $\mathrm{Ag} / \mathrm{AgCl}$ reference electrode were used [182]. Honokiol and magnolol were electrochemically oxidized using an acetylene black nanoparticle-modified glassy carbon electrode as a working electrode, with a platinum wire counter electrode and a saturated calomel reference electrode. The results indicated that the oxidation of honokiol was reversible and involved two electrons. The oxidation of magnolol was irreversible [183].
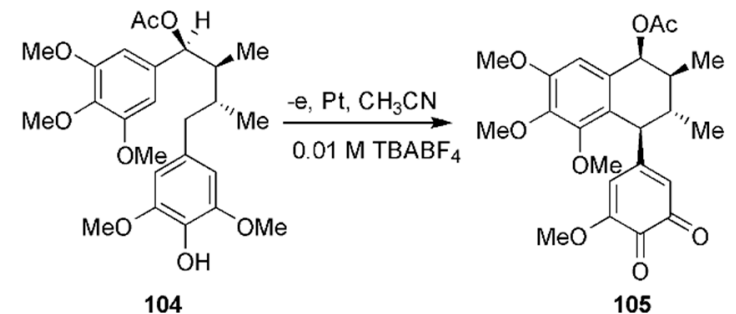

Scheme 49. Electrochemical oxidation of an acetoxy lignan to an o-quinone.
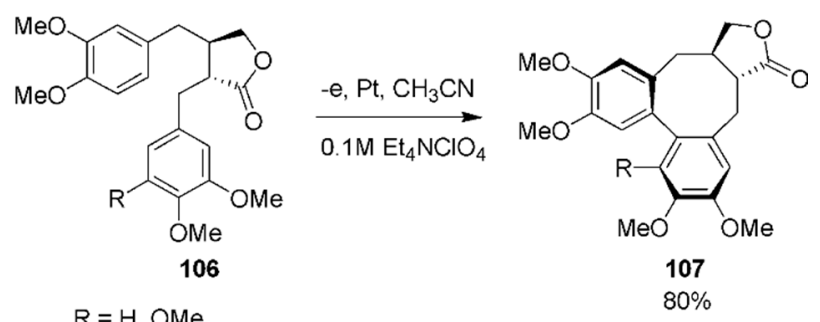

Scheme 50. Synthesis of dibenzocyclooctadienes by electrochemical oxidation of butyrolactone lignans.

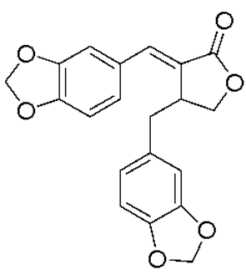

Hibalactone
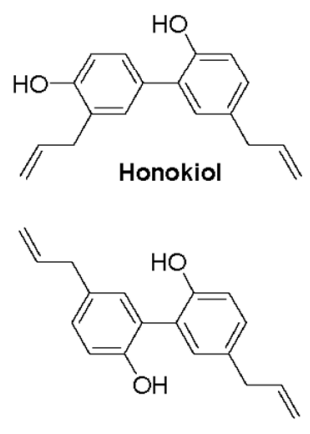

Magnolol<smiles>COc1ccc(C(c2ccc(O)c(OC)c2)c2ccc(O)c(OC)c2)cc1</smiles>

8'R-Epi-guaiacine 8 'S-Guaiacine<smiles>COc1cc(C2OC(c3ccc(O)c(OC)c3)C(C)=C2C)ccc1O</smiles>

8 'S-Verrucosine 8 'R-Nectandrin B<smiles>COc1cc([C@H]2Oc3cc([C@@H]4Oc5cc(O)cc(O)c5C(=O)C4O)ccc3O[C@H]2CO)ccc1O</smiles><smiles>COc1cc([C@H]2Oc3cc([C@@H]4Oc5cc(O)cc(O)c5C(=O)[C@H]4O)ccc3O[C@H]2CO)ccc1O</smiles>

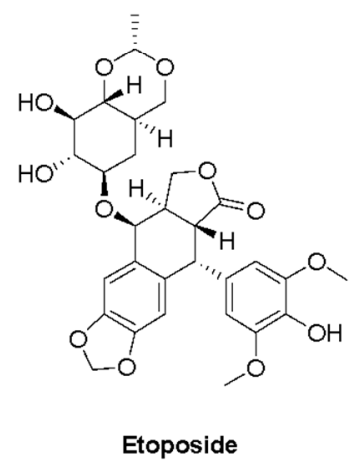

Figure 1. The structures of the lignans hibalactone, epi-guaiacin, guaiacin, verrucosin, nectandrin B, honokiol and magnolol, the glycoside etoposide, and the flavonolignan silybin. 
Foodstuff and plant extracts containing phenolic compounds including lignans have been electrochemically oxidized during the determination of the phenolic content [184-187] and the antioxidant capacity $[188,189]$. The drug etoposide, which is a semisynthetic epipodophyllotoxin glycoside, has been oxidized electrochemically using a carbon paste working electrode, a $\mathrm{Ag} / \mathrm{AgCl} / 3$ $\mathrm{M} \mathrm{KCl}$ reference electrode, and a platinum wire counter electrode, with a supporting electrolyte of varying $\mathrm{pH}$. The oxidation involves the transfer of two electrons and proceeds in one voltammetric oxidation step at a $\mathrm{pH}<4.0$ and two voltammetric oxidation steps at a $\mathrm{pH}>4.0$. In the first and reversible oxidation step, one electron is transferred, resulting in a stable radical. The product in the second oxidation step is an unstable cation, which rapidly converts into the o-quinone [190]. The flavonolignan silybin and its derivatives has been electrochemically oxidized using various methods [191-195].

\subsection{Photooxidations}

The lignans hydroxymatairesinol, allohydroxymatairesinol, $\alpha$-conidendrin, and oxo-matariresinol have been used as substrates for light-irradiation experiments in different solvents. The products of light-irradiation of hydroxymatairesinol that were either isolated or detected were allohydroxymatairesinol, oxomatairesinol, $\alpha$-conidendrin, allo-7'-methoxymatairesinol, $7^{\prime}$-methoxymatairesinol, and vanillin (Scheme 51). The irradiation of allo-hydroxymatairesinol formed the reaction products hydroxymatairesinol, oxomatairesinol, $\alpha$-conidendrin, allo- $7^{\prime}$-methoxymatairesinol, $7^{\prime}$-methoxymatairesinol, and vanillin. Oxomatairesinol was formed from the irradiation of hydroxymatairesinol, and vanillin from the irradiation of oxomatairesinol [162].

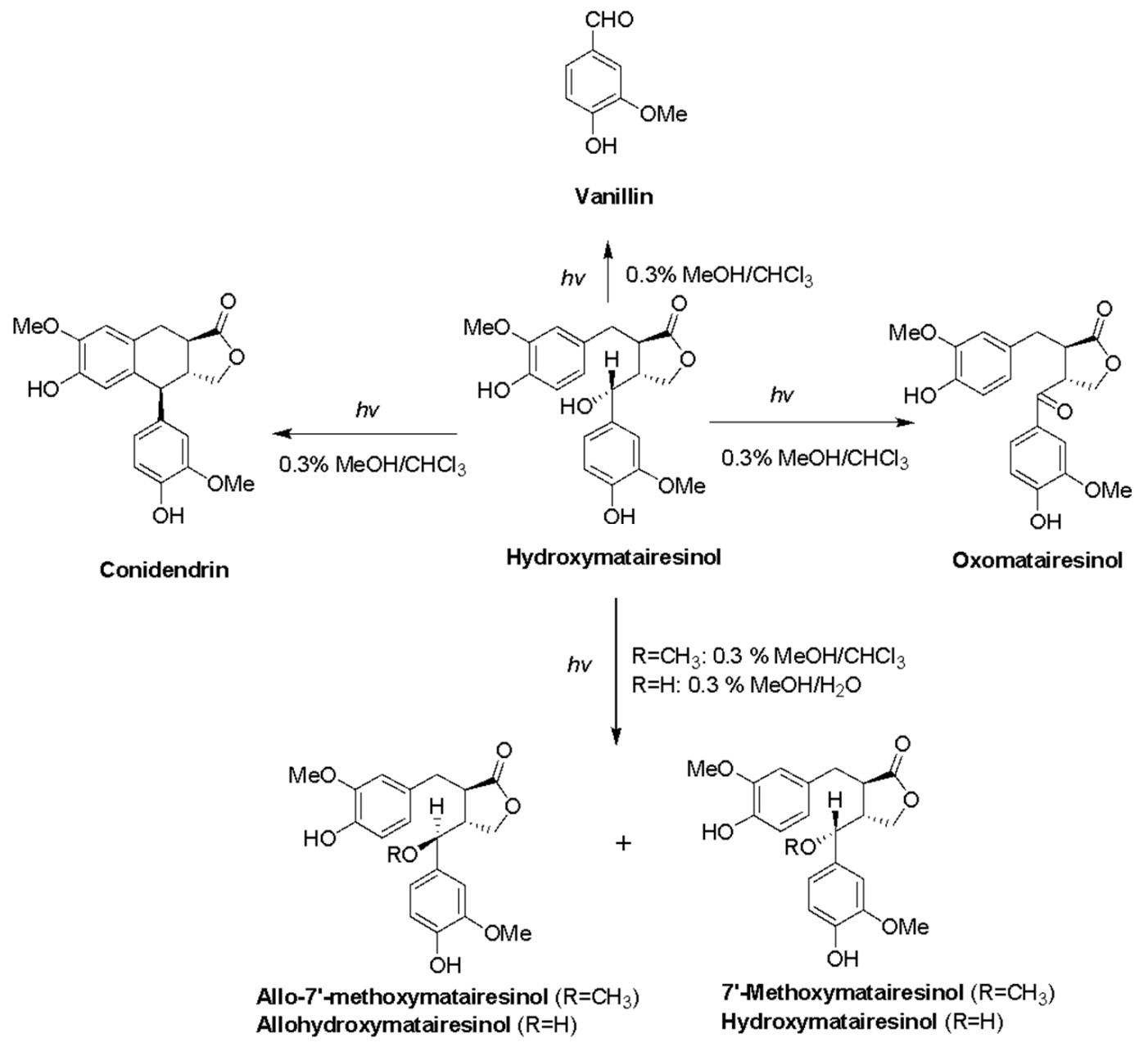

Scheme 51. The photooxidation reactions of hydroxymatairesinol. 


\section{Conclusions}

Lignans are oxidatively transformed in a number of processes and conditions. In nature, oxidations are mostly related to biosynthetic pathways, or processes where lignans act as primary antioxidant scavenging free radicals. When it comes to targeted oxidative transformations or studies between lignans and oxidants, the reports in the literature can be divided into non-metal mediated and metal mediated oxidations. The oxidative transformations include the oxidation of alcohols, both primary and benzylic, or benzylic functionalization by halogenation, hydroxylation, dehydrogenation, or by ring closing reactions. Oxidative Ar-Ar couplings forming cyclooctadienes have been extensively reported and can be quite selectively accomplished with several reagents in high yields. $\alpha$-Hydroxylations and epoxidations have also been reported, although to a much lesser extent and these reactions may warrant further investigations. Radical mediated oxidations often result in polymerization or radical addition reactions giving a wide range of products with poor selectivity, especially in the presence of free phenolic groups. Although there are over 200 papers reporting the oxidative transformations of lignans, we can conclude that there is still room for further investigations, especially concerning the selectivity. In addition, electrochemical oxidations and photooxidations are rather unexplored and could be a future area of research.

Funding: The authors would like to thank The Swedish Cultural Foundation in Finland (Svenska Kulturfonden) and Viktoriastiftelsen for financial support.

Conflicts of Interest: The authors declare no conflict of interest.

\section{References}

1. Zhang, J.; Chen, J.; Liang, Z.; Zhao, C. New Lignans and Their Biological Activities. Chem. Biodivers. 2014, 11, 1-54. [CrossRef] [PubMed]

2. Saleem, M.; Kim, H.J.; Ali, M.S.; Lee, Y.S. An update on bioactive plant lignans. Nat. Prod. Rep. 2005, 22, 696-716. [CrossRef] [PubMed]

3. Harmatha, J.; Dinan, L. Biological activities of lignans and stilbenoids associated with plant-insect chemical interactions. Phytochem. Rev. 2003, 2, 321-330. [CrossRef]

4. Talaei, M.; Pan, A. Role of phytoestrogens in prevention and management of type 2 diabetes. World J. Diabetes 2015, 6, 271-283. [CrossRef]

5. Deo, S.; Utane, R.; Khubalkar, R.; Thombre, S. Extraction and isolation, synthesis, physiological activity of 1-phenyl naphthalene and its derivatives: A review. Pharma Innov. J. 2017, 6, 21-30.

6. Teponno, R.B.; Kusari, S.; Spiteller, M. Recent advances in research on lignans and neolignans. Nat. Prod. Rep. 2016, 33, 1044-1092. [CrossRef] [PubMed]

7. Adlercreutz, H. Lignans and Human Health. Crit. Rev. Clin. Lab. Sci. 2007, 44, 483-525. [CrossRef]

8. Witkowska, A.M.; Waśkiewicz, A.; Zujko, M.E.; Szcześniewska, D.; Stepaniak, U.; Pająk, A.; Drygas, W. Are Total and Individual Dietary Lignans Related to Cardiovascular Disease and Its Risk Factors in Postmenopausal Women? A Nationwide Study. Nutrients 2018, 10, 865. [CrossRef]

9. Kiyama, R. Biological effects induced by estrogenic activity of lignans. Trends Food Sci. Technol. 2016, 54, 186-196. [CrossRef]

10. Bobe, G.; Murphy, G.; Albert, P.S.; Sansbury, L.B.; Lanza, E.; Schatzkin, A.; Cross, A.J. Dietary lignan and proanthocyanidin consumption and colorectal adenoma recurrence in the Polyp Prevention Trial. Int. J. Cancer 2012, 130, 1649-1659. [CrossRef]

11. Hearon, W.M.; MacGregor, W.S. The Naturally Occurring Lignans. Chem. Rev. 1955, 55, 957-1068. [CrossRef]

12. Rao, C. Chemistry of Lignans; Andhra University Press: Visakhapatnam, India, 1978.

13. Ayres, D.C.; Loike, J.D. Lignans: Chemical, Biological, and Clinical Properties; Phillipson, J.D., Ayres, D.C., Baxter, H., Eds.; Cambridge University Press: Cambridge, UK, 1990; ISBN 0521304210.

14. Whiting, D.A. Lignans, neolignans, and related compounds. Nat. Prod. Rep. 1987, 4, 499-525. [CrossRef] [PubMed]

15. Ward, R.S. Lignans, neolignans and related compounds. Nat. Prod. Rep. 1999, 16, 75-96. [CrossRef] 
16. Kariyappa, A.K.; Ramachandrappa, R.K.; Seena, S. Lignans: Insight to Chemistry and Pharmacological Applications-An Overview. Chem Sci Rev Lett. 2015, 4, 1157-1165.

17. Ward, R.S. Recent Advances in the Chemistry of Lignans. Stud. Nat. Prod. Chem. 2000, 24, 739-798. [CrossRef]

18. Pelter, A.; Ward, R.S.; Venkateswarlu, R.; Kamakshi, C. Oxidative transformations of lignans - reactions of dihydrocubebin and a derivative with DDQ. Tetrahedron 1991, 47, 1275-1284. [CrossRef]

19. Venkateswarlu, R.; Kamakshi, C.; Moinuddin, S.G.; Subhash, P.V.; Ward, R.S.; Pelter, A.; Hursthouse, M.B.; Light, M.E. Transformations of lignans, Part V. Reactions of DDQ with a gmelinol hydrogenolysis product and its derivatives. Tetrahedron 1999, 55, 13087-13108. [CrossRef]

20. Ward, R.S.; Hughes, D.D. Oxidative cyclisation of cis- and trans-2,3-dibenzylbutyrolactones using phenyl iodonium bis(trifluoroacetate) and 2,3-dichloro-5,6-dicyano-1,4-benzoquinone. Tetrahedron 2001, 57, 5633-5639. [CrossRef]

21. Charlton, J.L.; Chee, G.-L. Asymmetric synthesis of lignans using oxazolidinones as chiral auxiliaries. Can. J. Chem. 1997, 75, 1076-1083. [CrossRef]

22. Magoulas, G.; Papaioannou, D.; Magoulas, G.E.; Papaioannou, D. Bioinspired Syntheses of Dimeric Hydroxycinnamic Acids (Lignans) and Hybrids, Using Phenol Oxidative Coupling as Key Reaction, and Medicinal Significance Thereof. Molecules 2014, 19, 19769-19835. [CrossRef]

23. Satyanarayana, P.; Venkateswarlu, S.; Viswanatham, K.N. Oxidative aryl-aryl, aryl-benzyl coupling of lignans-reactions of phyllanthin and haloderivatives with TTFA, DDQ, Li/THF: synthesis of dibenzocyclooctadiene system and phyltetralin. Tetrahedron 1991, 47, 8277-8284. [CrossRef]

24. Pelter, A.; Ward, R.S.; Jones, D.M.; Maddocks, P. Asymmetric synthesis of lignans of the dibenzylbutanediol and tetrahydrodibenzocyclooctene series. J. Chem. Soc. Perkin Trans. 1 1993, 2631-2637. [CrossRef]

25. Pelter, A.; Ward, R.S.; Jones, D.M.; Maddocks, P. Asymmetric syntheses of lignans of the dibenzylbutyrolactone, dibenzylbutanediol, aryltetraun and dibenzocyclooctadiene series. Tetrahedron: Asymmetry 1992, 3, $239-242$. [CrossRef]

26. Chattopadhyay, S.K.; Rao, K.V. Chemistry of saururus cernuus IV: cyclooctadiene systems derived from austrobailignan-5. Tetrahedron 1987, 43, 669-678. [CrossRef]

27. Venkateswarlu, R.; Kamakshi, C.; Moinuddin, S.G.; Subhash, P.V.; Ward, R.S.; Pelter, A.; Coles, S.J.; Hursthouse, M.B.; Light, M.E. Transformations of lignans. Part 4: Oxidative and reductive rearrangements of dibenzocyclooctadiene and spirodienone lignans. Tetrahedron 2001, 57, 5625-5632. [CrossRef]

28. Tomioka, K.; Ishiguro, T.; Koga, K. First asymmetric total synthesis of (+)-steganacin determination of absolute stereochemistry. Tetrahedron Lett. 1980, 21, 2973-2976. [CrossRef]

29. Chang, J.; Xie, J. Synthesis of some new lignans and the mechanism of intramolecular nonphenolic oxidative coupling of aromatic compounds. Sci. China Ser. B Chem. 2000, 43, 323-330. [CrossRef]

30. Tilve, S.G.; Torney, P.S.; Patre, R.E.; Kamat, D.P.; Srinivasan, B.R.; Zubkov, F.I. Domino Wittig-Diels Alder reaction: Synthesis of carbazole lignans. Tetrahedron Lett. 2016, 57, 2266-2268. [CrossRef]

31. Ward, R.S.; Satyanarayana, P.; Gopala Rao, B.V. Reactions of Aryltetralin Lignans with DDQ—An Example of DDQ Oxidation of Allylic Ether Groups. Tetrahedron Lett. 1981, 22, 3021-3024. [CrossRef]

32. Yamaguchi, H.; Arimoto, M.; Tanoguchi, M.; Ishida, T.; Inoue, M. Studies on the constituents of the seeds of Hernandia ovigera L. III. Structures of two new lignans. Chem. Pharm. Bull. (Tokyo) 1982, 30, 3212-3218. [CrossRef]

33. Eklund, P.C.; Sjöholm, R.E. Oxidative transformation of the natural lignan hydroxymatairesinol with 2,3-dichloro-5,6-dicyano-1,4-benzoquinone. Tetrahedron 2003, 59, 4515-4523. [CrossRef]

34. Taskinen, A.; Eklund, P.; Sjöholm, R.; Hotokka, M. The molecular structure and some properties of hydroxymatairesinol. An ab initio study. J. Mol. Struct. THEOCHEM 2004, 677, 113-124. [CrossRef]

35. Ishiguro, T.; Mizuguchi, H.; Tomioka, K.; Koga, K. Stereoselective reactions. VIII. Stereochemical requirement for the benzylic oxidation of lignan lactone. A highly selective synthesis of the antitumor lignan lactone steganacin by the oxidation of stegane. Chem. Pharm. Bull. 1985, 33, 609-617. [CrossRef]

36. Ward, R.S.; Pelter, A.; Jack, I.R.; Satyanarayana, P.; Rao, B.V.G.; Subrahmanyam, P. Reactions of paulownin, gmelinol and gummadiol with 2,5-dichloro-5,6-dicyanobenzoquinone. Tetrahedron Lett. 1981, 22, 4111-4114. [CrossRef]

37. Ward, R.S.; Pelter, A.; Venkateswarlu, R.; Kamakshi, C.; Subhash, P.V.; Moinuddin, S.G.; Hursthouse, M.B.; Coles, S.J.; Hibbs, D.E. Transformations of lignans, part IV. Acid-catalysed rearrangements of gmelinol with 
$\mathrm{BF}_{3}$-etherate and study of a product with a unique lignan skeleton formed by further oxidation with DDQ. Tetrahedron 1999, 55, 13071-13086. [CrossRef]

38. Chang, J.B.; Xie, J.X. Synthesis of New Schizandrin Analogues. Chinese Chem. Lett. 2001, 12, 667-670.

39. Orito, K.; Sasaki, T.; Suginome, H. Photoinduced molecular transformations. 158. A total synthesis of (.+-.)-methyl piperitol: An unsymmetrically substituted 2,6-diaryl-3,7-dioxabicyclo [3.3.0] octane lignan. J. Org. Chem. 1995, 60, 6208-6210. [CrossRef]

40. Suginome, H.; Orito, K.; Yorita, K.; Ishikawa, M.; Shimoyama, N.; Sasaki, T. Photoinduced Molecular Transformations. 157. A New Stereo- and Regioselective Synthesis of 2,6-Diaryl-3,7 dioxabicyclo[3.3.0]octane Lignans Involving a $\beta$-Scission of Alkoxyl Radicals as the Key Step. New Total Syntheses of $( \pm)$-Sesamin, ( \pm )-Eudesmin, and. (+)-Yangambin. J. Org. Chem. 1995, 60, 3052-3064. [CrossRef]

41. Sato, Y.; Tamura, T.; Mori, M. Arylnaphthalene Lignans through Pd-Catalyzed[2+2+2] Cocyclization of Arynes and Diynes: Total Synthesis of Taiwanins C and E. Angew. Chem. Int. Ed. 2004, 43, 2436-2440. [CrossRef]

42. Peng, Y.; Xiao, J.; Xu, X.-B.; Duan, S.-M.; Ren, L.; Shao, Y.-L.; Wang, Y.-W. Stereospecific Synthesis of Tetrahydronaphtho[2,3-b]furans Enabled by a Nickel-Promoted Tandem Reductive Cyclization. Org. Lett. 2016, 18, 5170-5173. [CrossRef]

43. Sang, S.; Tian, S.; Wang, H.; Stark, R.E.; Rosen, R.T.; Yang, C.S.; Ho, C.-T. Chemical studies of the antioxidant mechanism of tea catechins: radical reaction products of epicatechin with peroxyl radicals. Bioorg. Med. Chem. 2003, 11, 3371-3378. [CrossRef]

44. Fujisawa, S.; Kadoma, Y. Comparative study of the alkyl and peroxy radical scavenging activities of polyphenols. Chemosphere 2006, 62, 71-79. [CrossRef] [PubMed]

45. Spatafora, C.; Daquino, C.; Tringali, C.; Amorati, R. Reaction of benzoxanthene lignans with peroxyl radicals in polar and non-polar media: Cooperative behaviour of OH groups. Org. Biomol. Chem. 2013, 11, 4291-4294. [CrossRef] [PubMed]

46. Masuda, T.; Akiyama, J.; Fujimoto, A.; Yamauchi, S.; Maekawa, T.; Sone, Y. Antioxidation reaction mechanism studies of phenolic lignans, identification of antioxidation products of secoisolariciresinol from lipid oxidation. Food Chem. 2010, 123, 442-450. [CrossRef]

47. Betigeri, S.; Thakur, A.; Raghavan, K. Use of 2,2'-Azobis(2-Amidinopropane) Dihydrochloride as a Reagent Tool for Evaluation of Oxidative Stability of Drugs. Pharm. Res. 2005, 22, 310-317. [CrossRef] [PubMed]

48. Pisoschi, A.M.; Negulescu, G.P. Methods for Total Antioxidant Activity Determination: A Review. Biochem. Anal. Biochem. 2011, 1. [CrossRef]

49. Amorati, R.; Zotova, J.; Baschieri, A.; Valgimigli, L. Antioxidant Activity of Magnolol and Honokiol: Kinetic and Mechanistic Investigations of Their Reaction with Peroxyl Radicals. J. Org. Chem. 2015, 80, 10651-10659. [CrossRef]

50. Werber, J.; Wang, Y.J.; Milligan, M.; Li, X.; Ji, J.A. Analysis of 2,2'-Azobis (2-Amidinopropane) Dihydrochloride Degradation and Hydrolysis in Aqueous Solutions. J. Pharm. Sci. 2011, 100, 3307-3315. [CrossRef]

51. Eklund, P.C.; Långvik, O.K.; Wärnå, J.P.; Salmi, T.O.; Willför, S.M.; Sjöholm, R.E. Chemical studies on antioxidant mechanisms and free radical scavenging properties of lignans. Org. Biomol. Chem. 2005, 3, 3336. [CrossRef]

52. Hosseinian, F.S.; Muir, A.D.; Westcott, N.D.; Krol, E.S. Antioxidant capacity of flaxseed lignans in two model systems. J. Am. Oil Chem. Soc. 2006, 83, 835. [CrossRef]

53. Kang, M.-H.; Naito, M.; Sakai, K.; Uchida, K.; Osawa, T. Mode of action of sesame lignans in protecting lowdensity lipoprotein against oxidative damage in vitro. Life Sci. 1999, 66, 161-171. [CrossRef]

54. Hodaj, E.; Tsiftsoglou, O.; Abazi, S.; Hadjipavlou-Litina, D.; Lazari, D. Lignans and indole alkaloids from the seeds of Centaurea vlachorum Hartvig (Asteraceae), growing wild in Albania and their biological activity. Nat. Prod. Res. 2017, 31, 1195-1200. [CrossRef] [PubMed]

55. Alphonse, P.A.S.; Aluko, R.E. Anti-carcinogenic and anti-metastatic effects of flax seed lignan secolariciresinol diglucoside (SDG). Discov. Phytomedicine 2015, 2, 12-17. [CrossRef]

56. Hosseinian, F.F.H. Antioxidant Properties of Flaxseed Lignans Using In Vitro Model Systems. Ph.D. Thesis, University of Saskatchewan, Saskatoon, SK, Canada, 2006.

57. Hosseinian, F.S.; Muir, A.D.; Westcott, N.D.; Krol, E.S. AAPH-mediated antioxidant reactions of secoisolariciresinol and SDG. Org. Biomol. Chem. 2007, 5, 644-654. [CrossRef] [PubMed] 
58. Narasimhan, N.S.; Aidhen, I.S. Radical mediated intramolecular arylation using tributyltinhydride/aibn: A formal synthesis of steganone. Tetrahedron Lett. 1988, 29, 2987-2988. [CrossRef]

59. Fischer, J.; Reynolds, A.J.; Sharp, L.A.; Sherburn, M.S. Radical Carboxyarylation Approach to Lignans. Total Synthesis of (-)-Arctigenin, (-)-Matairesinol, and Related Natural Products. Org. Lett. 2004, 6, 1345-1348. [CrossRef] [PubMed]

60. Huang, X.-X.; Bai, M.; Zhou, L.; Lou, L.-L.; Liu, Q.-B.; Zhang, Y.; Li, L.-Z.; Song, S.-J. Food Byproducts as a New and Cheap Source of Bioactive Compounds: Lignans with Antioxidant and Anti-inflammatory Properties from Crataegus pinnatifida Seeds. J. Agric. Food Chem. 2015, 63, 7252-7260. [CrossRef]

61. Chen, J.-J.; Wei, H.-B.; Xu, Y.-Z.; Zeng, J.; Gao, K. Antioxidant Lignans from the Roots of Vladimiria muliensis. Planta Med. 2013, 79, 1470-1473. [CrossRef]

62. Lee, E.-J.; Chen, H.-Y.; Hung, Y.-C.; Chen, T.-Y.; Lee, M.-Y.; Yu, S.-C.; Chen, Y.-H.; Chuang, I.-C.; Wu, T.-S. Therapeutic window for cinnamophilin following oxygen-glucose deprivation and transient focal cerebral ischemia. Exp. Neurol. 2009, 217, 74-83. [CrossRef] [PubMed]

63. Mocan, A.; Schafberg, M.; Crișan, G.; Rohn, S. Determination of lignans and phenolic components of Schisandra chinensis (Turcz.) Baill. using HPLC-ESI-ToF-MS and HPLC-online TEAC: Contribution of individual components to overall antioxidant activity and comparison with traditional antioxidant assays. J. Funct. Foods 2016, 24, 579-594. [CrossRef]

64. Sharma, O.P.; Bhat, T.K. DPPH antioxidant assay revisited. Food Chem. 2009, 113, 1202-1205. [CrossRef]

65. Szabo, M.; Idiţoiu, C.; Chambre, D.; Lupea, A. Improved DPPH determination for antioxidant activity spectrophotometric assay. Chem. Pap. 2007, 61, 214-216. [CrossRef]

66. Yamauchi, S.; Masuda, T.; Sugahara, T.; Kawaguchi, Y.; Ohuchi, M.; Someya, T.; Akiyama, J.; Tominaga, S.; Yamawaki, M.; Kishida, T.; Akiyama, K.; Maruyama, M. Antioxidant Activity of Butane Type Lignans, Secoisolariciresinol, Dihydroguaiaretic Acid, and 7,7'-Oxodihydroguaiaretic Acid. Biosci. Biotechnol. Biochem. 2008, 72, 2981-2986. [CrossRef] [PubMed]

67. Smeds, A.I.; Eklund, P.C.; Monogioudi, E.; Willför, S.M. Chemical characterization of polymerized products formed in the reactions of matairesinol and pinoresinol with the stable radical 2,2-diphenyl-1-picrylhydrazyl. Holzforschung 2012, 66, 283-294. [CrossRef]

68. Lei, M.; Hu, R.-J.; Wang, Y.-G. Mild and selective oxidation of alcohols to aldehydes and ketones using $\mathrm{NaIO}_{4} / \mathrm{TEMPO} / \mathrm{NaBr}$ system under acidic conditions. Tetrahedron 2006, 62, 8928-8932. [CrossRef]

69. Venkateswarlu, R.; Kamakshi, C.; Subhash, P.V.; Moinuddin, S.G.A.; Rama Sekhara Reddy, D.; Ward, R.S.; Pelter, A.; Gelbrich, T.; Hursthouse, M.B.; Coles, S.J.; et al. Transformations of lignans. Part 11: Oxidation of diphyllin with hypervalent iodine reagents and reductive reactions of a resulting 1-methoxy-1-aryl-4-oxonaphthalene lactone. Tetrahedron 2006, 62, 4463-4473. [CrossRef]

70. Pelter, A.; Ward, R.S.; Abd-El-Ghani, A. Preparation of dibenzocyclooctadiene lignans and spirodienones by hypervalent iodine oxidation of phenolic dibenzylbutyrolactones. J. Chem. Soc. Perkin Trans. 1 1992, 2249-2251. [CrossRef]

71. Ward, R.S.; Pelter, A.; Abd-El-Ghani, A. Preparation of tetrahydrodibenzocyclooctene lignans and spirodienones by hypervalent iodine oxidation of phenolic dibenzylbutyrolactones. Tetrahedron 1996, 52, 1303-1336. [CrossRef]

72. Pelter, A.; Satchwell, P.; Ward, R.S.; Blake, K. Effective, direct biomimetic synthesis of dibenzocyclooctene lignans by hypervalent iodine oxidation of phenolic dibenzylbutyrolactones. J. Chem. Soc. Perkin Trans. 1 1995, 2201-2202. [CrossRef]

73. Ward, R.S. Different strategies for the chemical synthesis of lignans. Phytochem. Rev. 2003, 2, 391-400. [CrossRef]

74. Albertson, A.K.F.; Lumb, J.P. A bio-inspired total synthesis of tetrahydrofuran lignans. Angew. Chem. Int. Ed. 2015, 54, 2204-2208. [CrossRef] [PubMed]

75. Bernini, R.; Barontini, M.; Mosesso, P.; Pepe, G.; Willför, S.M.; Sjöholm, R.E.; Eklund, P.C.; Saladino, R. A selective de-O-methylation of guaiacyl lignans to corresponding catechol derivatives by 2-iodoxybenzoic acid (IBX). The role of the catechol moiety on the toxicity of lignans. Org. Biomol. Chem. 2009, 7, 2367-2377. [CrossRef] [PubMed]

76. Ozanne, A.; Pouységu, L.; Depernet, D.; François, B.; Quideau, S. A Stabilized Formulation of IBX (SIBX) for Safe Oxidation Reactions Including a New Oxidative Demethylation of Phenolic Methyl Aryl Ethers. Org. Lett. 2003, 5, 2903-2906. [CrossRef] [PubMed] 
77. Gong, W.; RajanBabu, T.V. Conformation and reactivity in dibenzocyclooctadienes (DBCOD). A general approach to the total synthesis of fully substituted DBCOD lignans via borostannylative cyclization of a,w-diynes. Chem. Sci. 2013, 4, 3979. [CrossRef]

78. Reddel, J.C.T.; Lutz, K.E.; Diagne, A.B.; Thomson, R.J. Stereocontrolled Syntheses of Tetralone- and Naphthyl-Type Lignans by a One-Pot Oxidative [3,3] Rearrangement/Friedel-Crafts Arylation. Angew. Chem. Int. Ed. 2014, 53, 1395-1398. [CrossRef] [PubMed]

79. Pandey, G.; Luckorse, S.; Budakoti, A.; Puranik, V.G. Synthesis of optically pure 2,3,4-trisubstituted tetrahydrofurans via a two-step sequential Michael-Evans aldol cyclization strategy: total synthesis of (+)-magnolone. Tetrahedron Lett. 2010, 51, 2975-2978. [CrossRef]

80. Tohma, H.; Kita, Y. Hypervalent Iodine Reagents for the Oxidation of Alcohols and Their Application to Complex Molecule Synthesis. Adv. Synth. Catal. 2004, 346, 111-124. [CrossRef]

81. Koprowski, M.; Bałczewski, P.; Owsianik, K.; Różycka-Sokołowska, E.; Marciniak, B. Total synthesis of ( \pm )-epithuriferic acid methyl ester via Diels-Alder reaction. Org. Biomol. Chem. 2016, 14, 1822-1830. [CrossRef]

82. Jung, E.-K.; Dittrich, N.; Pilkington, L.I.; Rye, C.E.; Leung, E.; Barker, D. Synthesis of aza-derivatives of tetrahydrofuran lignan natural products. Tetrahedron 2015, 71, 9439-9456. [CrossRef]

83. Meresse, P.; Magiatis, P.; Bertounesque, E.; Monneret, C. Synthesis and antiproliferative activity of retroetoposide. Bioorg. Med. Chem. Lett. 2003, 13, 4107-4109. [CrossRef]

84. Meresse, P.; Monneret, C.; Bertounesque, E. Synthesis of podophyllotoxin analogues: $\delta$-lactone-containing picropodophyllin, podophyllotoxin and 4'-demethyl-epipodophyllotoxin derivatives. Tetrahedron 2004, 60, 2657-2671. [CrossRef]

85. Roulland, E.; Magiatis, P.; Arimondo, P.; Bertounesque, E.; Monneret, C. Hemi-synthesis and Biological Activity of New Analogues of Podophyllotoxin. Bioorg. Med. Chem. 2002, 10, 3463-3471. [CrossRef]

86. Reynolds, A.J.; Scott, A.J.; Turner, C.I.; Sherburn, M.S. The Intramolecular Carboxyarylation Approach to Podophyllotoxin. J. Am. Chem. Soc. 2003, 125, 12108-12109. [CrossRef] [PubMed]

87. Monovich, L.G.; Le Huérou, Y.; Rönn, M.; Molander, G.A. Total synthesis of (-)-steganone utilizing a samarium(II) iodide promoted 8-endo ketyl-olefin cyclization. J. Am. Chem. Soc. 2000, 122, 52-57. [CrossRef]

88. Davidson, S.J.; Pearce, A.N.; Copp, B.R.; Barker, D. Total Synthesis of (-)-Bicubebin A, B, (+)-Bicubebin C and Structural Reassignment of (-)-cis-Cubebin. Org. Lett. 2017, 19, 5368-5371. [CrossRef]

89. Roulland, E.; Bertounesque, E.; Huel, C.; Monneret, C. Synthesis of picropodophyllin homolactone. Tetrahedron Lett. 2000, 41, 6769-6773. [CrossRef]

90. Adler, E.; Hernestam, S.; Boss, E.; Caglieris, A. Estimation of Phenolic Hydroxyl Groups in Lignin. I. Periodate Oxidation of Guaiacol Compounds. Acta Chem. Scand. 1955, 9, 319-334. [CrossRef]

91. LaLonde, R.T.; Ramdayal, F.D.; Sarko, A.; Yanai, K.; Zhang, M. Modes of Methyleneoxy Bridging and Their Effect on Tetrahydronaphthalene Lignan Cytotoxicity. J. Med. Chem. 2003, 46, 1180-1190. [CrossRef]

92. Ayres, D.C.; Ritchie, T.J. Lignans and related phenols. Part 18. The synthesis of quinones from podophyllotoxin and its analogues. J. Chem. Soc. Perkin Trans. 1 1988, 2573-2578. [CrossRef]

93. Zhi, X.; Yu, X.; Yang, C.; Ding, G.; Chen, H.; Xu, H. Synthesis of $4 \beta$-acyloxypodophyllotoxin analogs modified in the $\mathrm{C}$ and $\mathrm{E}$ rings as insecticidal agents against Mythimna separata Walker. Bioorg. Med. Chem. Lett. 2014, 24, 765-772. [CrossRef]

94. Swigor, J.E.; Haynes, U.J. Synthesis of 4-o-(4,6-ethylidene- $\alpha$-D-glucopyranosyl)4'-demethyl-3'-O-[14C]methyl-4-epipodophyllotoxin. J. Label. Compd. Radiopharm. 1990, 28, 137-141. [CrossRef]

95. Nasveschuk, C.; Rovis, T. A Rapid Total Synthesis of ( \pm )-Sylvone. Synlett 2008, 126-128. [CrossRef]

96. Vitale, M.; Prestat, G.; Lopes, D.; Madec, D.; Kammerer, C.; Poli, G.; Girnita, L. New Picropodophyllin Analogs via Palladium-Catalyzed Allylic Alkylation-Hiyama Cross-Coupling Sequences. J. Org. Chem. 2008, 73, 5795-5805. [CrossRef] [PubMed]

97. Stadler, D.; Bach, T. Concise Stereoselective Synthesis of (-)-Podophyllotoxin by an Intermolecular Iron(III)-Catalyzed Friedel-Crafts Alkylation. Angew. Chem. Int. Ed. 2008, 47, 7557-7559. [CrossRef] [PubMed]

98. Mingoia, F.; Vitale, M.; Madec, D.; Prestat, G.; Poli, G. Pseudo-domino palladium-catalyzed allylic alkylation/Mizoroki-Heck coupling reaction: a key sequence toward ( \pm )-podophyllotoxin. Tetrahedron Lett. 2008, 49, 760-763. [CrossRef] 
99. Pullin, R.D.C.; Sellars, J.D.; Steel, P.G. Silenes in organic synthesis: a concise synthesis of ( \pm -epi-picropodophyllin. Org. Biomol. Chem. 2007, 5, 3201-3206. [CrossRef] [PubMed]

100. Akindele, T.; Marsden, S.P.; Cumming, J.G. Stereocontrolled Assembly of Tetrasubstituted Tetrahydrofurans: A Concise Synthesis of Virgatusin. Org. Lett. 2005, 7, 3685-3688. [CrossRef] [PubMed]

101. Tomioka, K.; Ishiguro, T.; Iitaka, Y.; Koga, K. Asymmetric total synthesis of natural (-)-and unnatural $(+)$-steganacin: Determination of the absolute configuration of natural antitumor steganacin. Tetrahedron 1984, 40, 1303-1312. [CrossRef]

102. Fan, J.-C.; Shang, Z.-C.; Liang, J.; Liu, X.-H.; Liu, Y. The oxidation of alcohols to aldehydes and ketones with $N$-bromosuccinimide in polyethylene glycol: an experimental and theoretical study. J. Phys. Org. Chem. 2008, 21, 945-953. [CrossRef]

103. Kende, A.S.; Liebeskind, L.S.; Mills, J.E.; Rutledge, P.S.; Curran, D.P. Oxidative aryl-benzyl coupling. A biomimetic entry to podophyllin lignan lactones. J. Am. Chem. Soc. 1977, 99, 7082-7083. [CrossRef]

104. Yamaguchi, H.; Nakajima, S.; Arimoto, M.; Tanoguchi, M.; Ishida, T.; Inoue, M. Studies on the constituents of the seeds of Hernandia ovigera L. IV. Syntheses of $\beta$-peltatin-A and -B methyl ethers from desoxypodophyllotoxin. Chem. Pharm. Bull. (Tokyo) 1984, 32, 1754-1760. [CrossRef]

105. Yamaguchi, H.; Arimoto, M.; Nakajima, S.; Tanoguchi, M.; Fukada, Y. Studies on the constituents of the seeds of Hernandia ovigera L. V Syntheses of epipodophyllotoxin and podophyllotoxin from desoxypodophyllotoxin. Chem. Pharm. Bull. (Tokyo) 1986, 34, 2056-2060. [CrossRef]

106. Ghosal, S.; Banerjee, S. Synthesis of retrochinensin; a new naturally occurring 4-aryl-2,3-naphthalide lignan. J. Chem. Soc. Chem. Commun. 1979, 0, 165-166. [CrossRef]

107. Banerji, J.; Das, B.; Chatterjee, A.; Shoolery, J.N. Gadain, a lignan from jatropha gossypifolia. Phytochemistry 1984, 23, 2323-2327. [CrossRef]

108. Mincione, E.; Sanetti, A.; Bernini, R.; Felici, M.; Bovicelli, P. Selective oxidation of lignan compounds by dimethyldioxirane. Diastereoselective opening of asarinin furo-furan skeleton. Tetrahedron Lett. 1998, 39, 8699-8702. [CrossRef]

109. MacLean, H.; Murakami, K. Lignans of western red cedar (Thuja plicata Donn) IV. Thujaplicutin and Thujaplicutin Methyl Ether. Can. J. Chem. 1966, 44, 1541-1545. [CrossRef]

110. MacLean, H.; Macdonald, B.F. Lignans of western red cedar (Thuja plicata Donn). VII. Dihydroxythujaplicatin. Can. J. Chem. 1967, 45, 739-740. [CrossRef]

111. Leopold, B.; Malmström, I.-L.; Holtermann, H.; Sörensen, J.S.; Sörensen, N.A. Nitrobenzene Oxidation of Compounds of the Lignan Type. Acta Chem. Scand. 1951, 5, 936-940. [CrossRef]

112. Wada, K.; Munakata, K. (-) Parabenzlactone, a new piperolignanolide isolated from nakai. Tetrahedron Lett. 1970, 11, 2017-2019. [CrossRef]

113. Yamauchi, S.; Sugahara, T.; Nakashima, Y.; Okada, A.; Akiyama, K.; Kishida, T.; Maruyama, M.; Masuda, T. Radical and Superoxide Scavenging Activities of Matairesinol and Oxidized Matairesinol. Biosci. Biotechnol. Biochem. 2006, 70, 1934-1940. [CrossRef]

114. Yamauchi, S.; Hayashi, Y.; Nakashima, Y.; Kirikihira, T.; Yamada, K.; Masuda, T. Effect of benzylic oxygen on the antioxidant activity of phenolic lignans. J. Nat. Prod. 2005, 68, 1459-1470. [CrossRef] [PubMed]

115. Brown, E.; Robin, J.P. A new route to the bis-benzocyclooctadiene lignan skeleton: Total syntheses of $( \pm)$ picrostegane, $( \pm)$ isopicrostegane and $( \pm)$ isostegane. Tetrahedron Lett. 1978, 19, 3613-3616. [CrossRef]

116. Hajra, S.; Garai, S.; Hazra, S. Catalytic Enantioselective Synthesis of (-)-Podophyllotoxin. Org. Lett. 2017, 19, 6530-6533. [CrossRef] [PubMed]

117. Xiao, J.; Cong, X.-W.; Yang, G.-Z.; Wang, Y.-W.; Peng, Y. Divergent Asymmetric Syntheses of Podophyllotoxin and Related Family Members via Stereoselective Reductive Ni-Catalysis. Org. Lett. 2018, 20, 1651-1654. [CrossRef] [PubMed]

118. Ogawa, M.; Ogihara, Y. Studies on the constituents of enkianthus nudipes. V. A new lignan xyloside from the stems. Chem. Pharm. Bull. (Tokyo) 1976, 24, 2102-2105. [CrossRef]

119. Brusentsev, Y.; Sandberg, T.; Hotokka, M.; Sjöholm, R.; Eklund, P. Synthesis and structural analysis of sterically hindered chiral 1,4-diol ligands derived from the lignan hydroxymatairesinol. Tetrahedron Lett. 2013, 54, 1112-1115. [CrossRef]

120. Brusentsev, Y.; Hänninen, M.; Eklund, P. Synthesis of Sterically Hindered Chiral 1,4-Diols from Different Lignan-Based Backbones. Synlett 2013, 24, 2423-2426. [CrossRef] 
121. Markus, H.; Plomp, A.J.; Sandberg, T.; Nieminen, V.; Bitter, J.H.; Murzin, D.Y. Dehydrogenation of hydroxymatairesinol to oxomatairesinol over carbon nanofibre-supported palladium catalysts. J. Mol. Catal. A Chem. 2007, 274, 42-49. [CrossRef]

122. Simakova, O.A.; Murzina, E.V.; Mäki-Arvela, P.; Leino, A.-R.; Campo, B.C.; Kordás, K.; Willför, S.M.; Salmi, T.; Murzin, D.Y. Oxidative dehydrogenation of a biomass derived lignan - Hydroxymatairesinol over heterogeneous gold catalysts. J. Catal. 2011, 282, 54-64. [CrossRef]

123. Simakova, O.A.; Smolentseva, E.; Estrada, M.; Murzina, E.V.; Beloshapkin, S.; Willför, S.M.; Simakov, A.V.; Murzin, D.Y. From woody biomass extractives to health-promoting substances: Selective oxidation of the lignan hydroxymatairesinol to oxomatairesinol over $\mathrm{Au}, \mathrm{Pd}$, and $\mathrm{Au}-\mathrm{Pd}$ heterogeneous catalysts. J. Catal. 2012, 291, 95-103. [CrossRef]

124. Simakova, O.A.; Murzina, E.V.; Leino, A.-R.R.; Mäki-Arvela, P.; Willför, S.; Murzin, D.Y. Gold Catalysts for Selective Aerobic Oxidation of the Lignan Hydroxymatairesinol to Oxomatairesinol: Catalyst Deactivation and Regeneration. Catal. Letters 2012, 142, 1011-1019. [CrossRef]

125. Prestianni, A.; Ferrante, F.; Simakova, O.A.; Duca, D.; Murzin, D.Y. Oxygen-Assisted Hydroxymatairesinol Dehydrogenation: A Selective Secondary-Alcohol Oxidation over a Gold Catalyst. Chem. Eur. J. 2013, 19, 4577-4585. [CrossRef] [PubMed]

126. López, M.; Simakova, O.A.; Murzina, E.V.; Willför, S.M.; Prosvirin, I.; Simakov, A.; Murzin, D.Y. Gold particle size effect in biomass-derived lignan hydroxymatairesinol oxidation over $\mathrm{Au} / \mathrm{Al}_{2} \mathrm{O}_{3}$ catalysts. Appl. Catal. A Gen. 2015, 504, 248-255. [CrossRef]

127. Khamlach, K.; Dhal, R.; Brown, E. Total syntheses of (-)-trachelogenin, (-)-nortrachelogenin and (+)-wikstromol. Tetrahedron Lett. 1989, 30, 2221-2224. [CrossRef]

128. Mäkelä, T.H.; Kaltia, S.A.; Wähälä, K.T.; Hase, T.A. $\alpha, \beta$-Dibenzyl- $\gamma$-butyrolactone lignan alcohols: Total synthesis of $( \pm)-7^{\prime}$-hydroxyenterolactone, $( \pm)$-7'-hydroxymatairesinol and $( \pm)$-8-hydroxyenterolactone. Steroids 2001, 66, 777-784. [CrossRef]

129. Chen, B.-C.; Zhou, P.; Davis, F.A.; Ciganek, E. $\alpha$-Hydroxylation of Enolates and Silyl Enol Ethers. In Organic Reactions; John Wiley \& Sons, Inc.: Hoboken, NJ, USA, 2003; pp. 1-356. ISBN 9780471264187.

130. Moritani, Y.; Fukushima, C.; Ukita, T.; Miyagishima, T.; Ohmizu, H.; Iwasaki, T. Stereoselective syntheses of cisand trans-isomers of $\alpha$-hydroxy- $\alpha, \beta$-dibenzyl- $\gamma$-butyrolactone lignans: New syntheses of $( \pm)$-trachelogenin and ( \pm )-guayadequiol. J. Org. Chem. 1996, 61, 6922-6930. [CrossRef] [PubMed]

131. Moritani, Y.; Ukita, T.; Hiramatsu, H.; Okamura, K.; Ohmizu, H.; Iwasaki, T. A highly stereoselective synthesis of 3-hydroxy-1-aryltetralin lignans based on the stereoselective hydroxylation of $\alpha, \beta$-dibenzyl- $\gamma$-butyro-lactones: the first synthesis of $( \pm)$-cycloolivil. J. Chem. Soc., Perkin Trans. 1 1996, 0 , 2747-2753. [CrossRef]

132. Kramer, B.; Fröhlich, R.; Waldvogel, S.R. Oxidative Coupling Reactions Mediated by $\mathrm{MoCl}_{5}$ Leading to 2,2'-Cyclolignans: The Specific Role of HCl. Eur. J. Org. Chem. 2003, 18, 3549-3554. [CrossRef]

133. Kramer, B.; Averhoff, A.; Waldvogel, S.R. Highly selective formation of eight-membered-ring systems by oxidative cyclization with molybdenum pentachloride-An environmentally friendly and inexpensive access to 2,2'-cyclolignans. Angew. Chem. Int. Ed. 2002, 41, 2981-2982. [CrossRef]

134. Damon, R.E.; Schlessinger, R.H.; Blount, J.F. A short synthesis of (.+-.)-isostegane. J. Org. Chem. 1976, 41, 3772-3773. [CrossRef]

135. Landais, Y.; Lebrun, A.; Robin, J.P. Ruthenium(IV) tetrakis(trifluoroacetate), a new oxidizing agent. II. A new access to schizandrins skeleton using biaryl oxidative coupling of cis-substituted butanolides. Tetrahedron Lett. 1986, 27, 5377-5380. [CrossRef]

136. Landais, Y.; Robin, J.-P. Le tétrakis (trifluoroacétate) de ruthénium(IV), nouveau catalyseur a température ambiante du couplage biarylique oxydant non phénolique -première synthèse totale biomimétique du néoisostégane-. Tetrahedron Lett. 1986, 27, 1785-1788. [CrossRef]

137. Robin, J.P.; Landais, Y. Ruthenium(IV) dioxide in fluoro acid medium. An efficient biaryl phenol coupling process, exemplified with a biomimetic access to the skeleton of steganacin from presteganes. J. Org. Chem. 1988, 53, 224-226. [CrossRef]

138. Landais, Y.; Robin, J.-P.; Lebrun, A. Ruthenium dioxide in fluoro acid medium: I. A new agent in the biaryl oxidative coupling. Application to the synthesis of non phenolic bisbenzocyclooctadiene lignan lactones. Tetrahedron 1991, 47, 3787-3804. [CrossRef] 
139. Robin, J.-P.; Landais, Y. Ruthenium dioxide in fluoro acid medium: II. Application to the formation of steganes skeleton by oxidative phenolic coupling. Tetrahedron 1992, 48, 819-830. [CrossRef]

140. Dhal, R.; Landais, Y.; Lebrun, A.; Lenain, V.; Robin, J.-P. Ruthenium dioxide in fluoro acid medium V. Application to the non phenolic oxidative coupling of diarylbutanes. Conformational studies of cis and trans deoxyschizandrins. Tetrahedron 1994, 50, 1153-1164. [CrossRef]

141. Pettit, G.R.; Meng, Y.; Gearing, R.P.; Herald, D.L.; Pettit, R.K.; Doubek, D.L.; Chapuis, J.-C.; Tackett, L.P. Antineoplastic Agents. 522. Hernandia peltata (Malaysia) and Hernandia nymphaeifolia (Republic of Maldives). J. Nat. Prod. 2004, 67, 214-220. [CrossRef]

142. Landais, Y.; Lebrun, A.; Lenain, V.; Robin, J.-P. Synthesis of diarylbutanes from cordigerines and reinvestigation of their oxidative couplings in deoxyschizandrins.-An unusual formation of phenyltetralin lignans -. Tetrahedron Lett. 1987, 28, 5161-5164. [CrossRef]

143. Cambie, R.; Craw, P.; Rutledge, P.; Woodgate, P. Oxidative Coupling of Lignans. III. Non-Phenolic Oxidative Coupling of Deoxypodorhizon and Related Compounds. Aust. J. Chem. 1988, 41, 897-918. [CrossRef]

144. Burden, J.; Cambie, R.; Craw, P.; Rutledge, P.; Woodgate, P. Oxidative Coupling of Lignans. IV. Monophenolic Oxidative Coupling. Aust. J. Chem. 1988, 41, 919-933. [CrossRef]

145. Planchenault, D.; Dhal, R.; Robin, J.-P. New agents of biaryl oxidative coupling in fluoro acid medium. VI. Application to the synthesis of phenolic bisbenzocyclooctadiene lignans. Tetrahedron 1995, 51, 1395-1404. [CrossRef]

146. Ward, R.S.; Hughes, D.D. Oxidative cyclisation of cis- and trans-2,3-dibenzylbutyrolactones using ruthenium tetra(trifluoroacetate). Tetrahedron 2001, 57, 4015-4022. [CrossRef]

147. Planchenault, D.; Dhal, R.; Robin, J.-P. Synthesis of non-phenolic bisbenzocyclooctadiene lignan lactones and aporphinic alkaloids, by oxidative coupling with new agents in fluoro acid medium. IV. Tetrahedron 1993, 49, 5823-5830. [CrossRef]

148. Saladino, R.; Fiani, C.; Belfiore, M.C.; Gualandi, G.; Penna, S.; Mosesso, P. Methyltrioxorhenium catalysed synthesis of highly oxidised aryltetralin lignans with anti-topoisomerase II and apoptogenic activities. Bioorganic Med. Chem. 2005, 13, 5949-5960. [CrossRef] [PubMed]

149. Saladino, R.; Fiani, C.; Crestini, C.; Argyropoulos, D.S.; Marini, S.; Coletta, M. An Efficient and Stereoselective Dearylation of Asarinin and Sesamin Tetrahydrofurofuran Lignans to Acuminatolide by Methyltrioxorhenium/ $\mathrm{H}_{2} \mathrm{O}_{2}$ and UHP Systems. J. Nat. Prod. 2007, 70, 39-42. [CrossRef]

150. Bernini, R.; Gualandi, G.; Crestini, C.; Barontini, M.; Belfiore, M.C.; Willför, S.; Eklund, P.; Saladino, R. A novel and efficient synthesis of highly oxidized lignans by a methyltrioxorhenium/hydrogen peroxide catalytic system. Studies on their apoptogenic and antioxidant activity. Bioorg. Med. Chem. 2009, 17, 5676-5682. [CrossRef] [PubMed]

151. Nishibe, S.; Chiba, M.; Sakushima, A.; Hisada, S.; Yamanouchi, S.; Takido, M.; Sankawa, U.; Sakakibara, A. Introduction of an alcoholic hydroxyl group into 2,3-dibenzylbutyrolactone lignans with oxidizing agents and carbon-13 nuclear magnetic resonance spectra of the oxidation products. Chem. Pharm. Bull. (Tokyo) 1980, 28, 850-860. [CrossRef]

152. Pohmakotr, M.; Pinsa, A.; Mophuang, T.; Tuchinda, P.; Prabpai, S.; Kongsaeree, P.; Reutrakul, V. General strategy for stereoselective synthesis of 1-substituted Exo,Endo-2,6-diaryl-3,7-dioxabicyclo[3.3.0]octanes: Total synthesis of ( \pm )-gmelinol. J. Org. Chem. 2006, 71, 386-389. [CrossRef]

153. Takemoto, M.; Aoshima, Y.; Stoynov, N.; Kutney, J.P. Establishment of Camellia sinensis cell culture with high peroxidase activity and oxidative coupling reaction of dibenzylbutanolides. Tetrahedron Lett. 2002, 43, 6915-6917. [CrossRef]

154. Takemoto, M.; Fukuyo, A.; Aoshima, Y.; Tanaka, K. Synthesis of Lyoniresinol with Combined Utilization of Synthetic Chemistry and Biotechnological Methods. Chem. Pharm. Bull. (Tokyo) 2006, 54, 226-229. [CrossRef]

155. Kutney, J.P.; Xinyao, D.; Naidu, R.; Stoynov, N.M.; Takemoto, M. Biotransformation of Dibenzylbutanolides by Peroxidase Enzymes. Routes to the Podophyllotoxin Family. Heterocycles 1996, 42, 479-484. [CrossRef]

156. Yue, F.; Lu, F.; Ralph, S.; Ralph, J. Identification of 4-O-5-Units in Softwood Lignins via Definitive Lignin Models and NMR. Biomacromolecules 2016, 17, 1909-1920. [CrossRef] [PubMed]

157. Moinuddin, S.G.A.; Youn, B.; Bedgar, D.L.; Costa, M.A.; Helms, G.L.; Kang, C.; Davin, L.B.; Lewis, N.G. Secoisolariciresinol dehydrogenase: mode of catalysis and stereospecificity of hydride transfer in Podophyllum peltatum. Org. Biomol. Chem. 2006, 4, 808-816. [CrossRef] [PubMed] 
158. Murata, J.; Ono, E.; Yoroizuka, S.; Toyonaga, H.; Shiraishi, A.; Mori, S.; Tera, M.; Azuma, T.; Nagano, A.J.; Nakayasu, M.; Mizutani, M.; Wakasugi, T.; Yamamoto, M.P.; Horikawa, M. Oxidative rearrangement of (+)-sesamin by CYP92B14 co-generates twin dietary lignans in sesame. Nat. Commun. 2017, 8, 2155. [CrossRef] [PubMed]

159. Vasilev, N.P.; Julsing, M.K.; Koulman, A.; Clarkson, C.; Woerdenbag, H.J.; Ionkova, I.; Bos, R.; Jaroszewski, J.W.; Kayser, O.; Quax, W.J. Bioconversion of deoxypodophyllotoxin into epipodophyllotoxin in E. coli using human cytochrome P450 3A4. J. Biotechnol. 2006, 126, 383-393. [CrossRef]

160. Krauss, A.S.; Taylor, W.C. Intramolecular Oxidative Coupling of Aromatic Compounds. III. Monophenolic Substrates. Aust. J. Chem. 1992, 45, 925-933. [CrossRef]

161. Fernandes, J.B.; Fraga, R.L.; Capelato, M.D.; Vierira, P.C.; Yoshida, M.; Kato, M.J. Synthesis of Dibenzocyclooctadienes by Anodic Oxidation. Synth. Commun. 1991, 21, 1331-1336. [CrossRef]

162. Kawamura, F.; Miyachi, M.; Kawai, S.; Ohashi, H. Photodiscoloration of western hemlock (Tsuga heterophylla) sapwood III Early stage of photodiscoloration reaction with lignans. J. Wood Sci. 1998, 44, 47-55. [CrossRef]

163. Litescu, S.C.; Eremia, S.A.V.; Tache, A.; Vasilescu, I.; Radu, G.-L. The Use of Oxygen Radical Absorbance Capacity (ORAC) and Trolox Equivalent Antioxidant Capacity (TEAC) Assays in the Assessment of Beverages' Antioxidant Properties. In Processing and Impact on Antioxidants in Beverages; Preedy, V., Ed.; Elsevier: Amsterdam, The Netherlands, 2014; pp. 245-251. ISBN 978-0-12-404738-9.

164. Golubev, V.A.; Rozantsev, E.G.; Neiman, M.B. Some reactions of free iminoxyl radicals with unpaired electron participation. Izv. Akad. Nauk SSSR Ser. Khim. 1965, 11, 1927-1936. [CrossRef]

165. Merbouh, N.; Bobbitt, J.M.; Brückner, C. Preparation of Tetramethylpiperidine-1-oxoammonium Salts And Their Use As Oxidants In Organic Chemistry. A Review. Org. Prep. Proced. Int. 2004, 36, 1-31. [CrossRef]

166. Tojo, G.; Fernández, M.I. TEMPO-Mediated Oxidations. In Oxidation of Primary Alcohols to Carboxylic Acids; Springer: New York, NY, USA, 2007; pp. 79-103.

167. Nandanwar, R.A.; Chaudhari, A.R.; Ekhe, J.D. Nitrobenzene Oxidation for Isolation of Value Added Products from Industrial Waste Lignin. J. Chem. Biol. Phys. Sci. 2016, 6, 501-513.

168. Pezzella, C.; Guarino, L.; Piscitelli, A. How to enjoy laccases. Cell. Mol. Life Sci. 2015, 72, 923-940. [CrossRef] [PubMed]

169. Huis, R.; Morreel, K.; Fliniaux, O.; Lucau-Danila, A.; Fénart, S.; Grec, S.; Neutelings, G.; Chabbert, B.; Mesnard, F.; Boerjan, W.; Hawkins, S. Natural hypolignification is associated with extensive oligolignol accumulation in flax stems. Plant Physiol. 2012, 158, 1893-1915. [CrossRef] [PubMed]

170. Glazunova, O.A.; Trushkin, N.A.; Moiseenko, K.V.; Filimonov, I.S.; Fedorova, T.V. Catalytic Efficiency of Basidiomycete Laccases: Redox Potential versus Substrate-Binding Pocket Structure. Catalysts 2018, 8, 152. [CrossRef]

171. Moya, R.; Saastamoinen, P.; Hernández, M.; Suurnäkki, A.; Arias, E.; Mattinen, M.-L. Reactivity of bacterial and fungal laccases with lignin under alkaline conditions. Bioresour. Technol. 2011, 102, 10006-10012. [CrossRef] [PubMed]

172. Buchert, J.; Mustranta, A.; Tamminen, T.; Spetz, P.; Holmbom, B. Modification of Spruce Lignans with Trametes hirsuta Laccase. Holzforschung 2002, 56, 579-584. [CrossRef]

173. Maijala, P.; Mattinen, M.-L.; Nousiainen, P.; Kontro, J.; Asikkala, J.; Sipilä, J.; Viikari, L. Action of fungal laccases on lignin model compounds in organic solvents. J. Mol. Catal. B Enzym. 2012, 76, 59-67. [CrossRef]

174. Mattinen, M.-L.; Maijala, P.; Nousiainen, P.; Smeds, A.; Kontro, J.; Sipilä, J.; Tamminen, T.; Willför, S.; Viikari, L. Oxidation of lignans and lignin model compounds by laccase in aqueous solvent systems. J. Mol. Catal. B Enzym. 2011, 72, 122-129. [CrossRef]

175. Mattinen, M.-L.; Struijs, K.; Suortti, T.; Mattila, I.; Kruus, K.; Willför, S.; Tamminen, T.; Vincken, J.-P. Modification of Lignans by Trameter Hirsuta Laccase. BioResources 2009, 4, 482-496. [CrossRef]

176. Frív, I.; Siverio, J.M.; González, C.; Trujillo, J.M.; Pérez, J.A. Purification of a new peroxidase catalysing the formation of lignan-type compounds. Biochem. J. 1991, 273 (Pt 1), 109-113. [CrossRef]

177. Hazra, S.; Chattopadhyay, S. An overview of lignans with special reference to podophyllotoxin, a cytotoxic lignan. Chem. Biol. Lett. 2016, 3, 1-8.

178. Nakatsubo, T.; Mizutani, M.; Suzuki, S.; Hattori, T.; Umezawa, T. Characterization of Arabidopsis thaliana Pinoresinol Reductase, a New Type of Enzyme Involved in Lignan Biosynthesis. J. Biol. Chem. 2008, 283, 15550-15557. [CrossRef] 
179. Xia, Z.Q.; Costa, M.A.; Pelissier, H.C.; Davin, L.B.; Lewis, N.G. Secoisolariciresinol dehydrogenase purification, cloning, and functional expression. Implications for human health protection. J. Biol. Chem. 2001, 276, 12614-12623. [CrossRef] [PubMed]

180. Van Uden, W.; Bos, J.A.; Boeke, G.M.; Woerdenbag, H.J.; Pras, N. The Large-Scale Isolation of Deoxypodophyllotoxin from Rhizomes of Anthriscus sylvestris Followed by Its Bioconversion into 5-Methoxypodophyllotoxin $\beta$ - d -Glucoside by Cell Cultures of Linum flavum. J. Nat. Prod. 1997, 60, 401-403. [CrossRef]

181. Oliveira, T.L.S.; de Siqueira Leite, K.C.; de Macêdo, I.Y.L.; de Morais, S.R.; Costa, E.A.; de Paula, J.R.; de Souza Gil, E. Electrochemical Behavior and Antioxidant Activity of Hibalactone. Int. J. Electrochem. Sci. 2017, 12, 7596-7964. [CrossRef]

182. Silva, D.H.S.; Pereira, F.C.; Zanoni, M.V.B.; Yoshida, M. Lipophyllic antioxidants from Iryanthera juruensis fruits. Phytochemistry 2001, 57, 437-442. [CrossRef]

183. Yang, X.; Gao, M.; Hu, H.; Zhang, H. Electrochemical detection of honokiol and magnolol in traditional Chinese medicines using acetylene black nanoparticle-modified Electrode. Phytochem. Anal. 2011, 22, 291-295. [CrossRef] [PubMed]

184. Enache, T.A.; Amine, A.; Brett, C.M.A.; Oliveira-Brett, A.M. Virgin olive oil ortho-phenols—electroanalytical quantification. Talanta 2013, 105, 179-186. [CrossRef]

185. Natale, A.; Nardiello, D.; Palermo, C.; Muscarella, M.; Quinto, M.; Centonze, D. Development of an analytical method for the determination of polyphenolic compounds in vegetable origin samples by liquid chromatography and pulsed amperometric detection at a glassy carbon electrode. J. Chromatogr. A 2015, 1420, 66-73. [CrossRef]

186. Fernández, E.; Vidal, L.; Canals, A. Rapid determination of hydrophilic phenols in olive oil by vortex-assisted reversed-phase dispersive liquid-liquid microextraction and screen-printed carbon electrodes. Talanta 2018, 181, 44-51. [CrossRef]

187. Apetrei, I.M.; Apetrei, C. Voltammetric e-tongue for the quantification of total polyphenol content in olive oils. Food Res. Int. 2013, 54, 2075-2082. [CrossRef]

188. Przygodzka, M.; Zielińska, D.; Ciesarová, Z.; Kukurová, K.; Zieliński, H. Comparison of methods for evaluation of the antioxidant capacity and phenolic compounds in common spices. LWT - Food Sci. Technol. 2014, 58, 321-326. [CrossRef]

189. Rivas Romero, M.P.; Estévez Brito, R.; Rodríguez Mellado, J.M.; González-Rodríguez, J.; Ruiz Montoya, M.; Rodríguez-Amaro, R. Exploring the relation between composition of extracts of healthy foods and their antioxidant capacities determined by electrochemical and spectrophotometrical methods. LWT 2018, 95, 157-166. [CrossRef]

190. Radi, A.-E.; Abd-Elghany, N.; Wahdan, T. Electrochemical study of the antineoplastic agent etoposide at carbon paste electrode and its determination in spiked human serum by differential pulse voltammetry. Chem. Pharm. Bull. (Tokyo) 2007, 55, 1379-1382. [CrossRef] [PubMed]

191. Hassan, E.M.; Khamis, E.F.; El-Kimary, E.I.; Barary, M.A. Development of a differential pulse voltammetric method for the determination of Silymarin/Vitamin E acetate mixture in pharmaceuticals. Talanta 2008, 74, 773-778. [CrossRef] [PubMed]

192. El-Desoky, H.S.; Ghoneim, M.M. Stripping voltammetric determination of silymarin in formulations and human blood utilizing bare and modified carbon paste electrodes. Talanta 2011, 84, 223-234. [CrossRef] [PubMed]

193. Mpanza, T.; Sabela, M.I.; Mathenjwa, S.S.; Kanchi, S.; Bisetty, K. Electrochemical Determination of Capsaicin and Silymarin Using a Glassy Carbon Electrode Modified by Gold Nanoparticle Decorated Multiwalled Carbon Nanotubes. Anal. Lett. 2014, 47, 2813-2828. [CrossRef]

194. Gažák, R.; Svobodová, A.; Psotová, J.; Sedmera, P.; Přikrylová, V.; Walterová, D.; Křen, V. Oxidised derivatives of silybin and their antiradical and antioxidant activity. Bioorganic Med. Chem. 2004, 12, 5677-5687. [CrossRef]

195. Kosina, P.; Kren, V.; Gebhardt, R.; Grambal, F.; Ulrichova, J.; Walterova, D. Antioxidant properties of silybin glycosides. Phytother Res 2002, 16, 33-39. [CrossRef]

(C) 2019 by the authors. Licensee MDPI, Basel, Switzerland. This article is an open access article distributed under the terms and conditions of the Creative Commons Attribution (CC BY) license (http://creativecommons.org/licenses/by/4.0/). 